\title{
A Review of Solar Energy Harvesting Electronic Textiles
}

\author{
Achala Satharasinghe ${ }^{1,2} \mathbb{D}$, Theodore Hughes-Riley ${ }^{1, * \mathbb{D}}$ and Tilak Dias ${ }^{1}$ (D) \\ 1 Advanced Textiles Research Group, School of Art and Design, Nottingham Trent University, Bonington \\ Building, Dryden Street, Nottingham NG1 4GG, UK; achala.satharasinghe2016@my.ntu.ac.uk (A.S.); \\ tilak.dias@ntu.ac.uk (T.D.) \\ 2 MAS Innovations (pvt) Ltd., 50 Foster Lane, Colombo 10 01000, Sri Lanka \\ * Correspondence: theodore.hughesriley@ntu.ac.uk; Tel.: +44-(0)1158-488-178
}

Received: 18 September 2020; Accepted: 19 October 2020; Published: 21 October 2020

\begin{abstract}
An increased use in wearable, mobile, and electronic textile sensing devices has led to a desire to keep these devices continuously powered without the need for frequent recharging or bulky energy storage. To achieve this, many have proposed integrating energy harvesting capabilities into clothing: solar energy harvesting has been one of the most investigated avenues for this due to the abundance of solar energy and maturity of photovoltaic technologies. This review provides a comprehensive, contemporary, and accessible overview of electronic textiles that are capable of harvesting solar energy. The review focusses on the suitability of the textile-based energy harvesting devices for wearable applications. While multiple methods have been employed to integrate solar energy harvesting with textiles, there are only a few examples that have led to devices with textile properties.
\end{abstract}

Keywords: electronic textiles; E-textile; smart textile; energy harvesting; photovoltaic textile; solar energy; solar cell; thin film

\section{Introduction}

For applications such as on-body sensing, electronic textiles (E-textiles) offer a distinct advantage over many other wearable and mobile devices as they are comfortable to wear close to the skin. Ideally an E-textile will possess all of the properties of a normal textile including heat and moisture transfer characteristics, shear deformability, flexibility, drape, and breathability. In addition, an E-textile should be able to survive repeated mechanical deformations, and be wash durable. While these properties are not present for all E-textiles, recent developments have led to devices with superior textile characteristics [1-5].

A typical sensing system consists of four main components; the sensing device, a data processing module (incorporating data acquisition, data storage or transmission, etc.), interconnections between the two, and a power supply. To date, much of the research regarding E-textile sensing systems has focused on creating textile sensors and interconnections, with data processing and power provided by a non-textile solution (i.e., Lithium Polymer batteries).

A robust and user-friendly power supply remains an unfulfilled need for many wearable E-textile devices, which is a major hurdle to the wider adoption of E-textiles [6,7]. Such a power supply is also desirable for powering other wearable and mobile devices to minimize the need for recharging. To address this requirement, there has been a significant effort in recent years to develop textile-based energy solutions, which take the form of energy storage [8,9] and energy harvesting devices [10,11], as covered by multiple excellent reviews in the literature. Of the energy harvesting technologies explored for wearables, solar energy harvesting has been one of the most investigated avenues due to 
the abundance of solar energy and the maturity of photovoltaic (PV) technologies [12]. While other reviews on photovoltaic textiles exist [13-17], this review will focus on the key textile properties of the reported photovoltaic textiles. This review is designed to be a useful resource to those working in many different areas of E-textiles, and has been written to be accessible to non-specialists. The purpose of this review is not to deeply discuss chemistries or specific material processes.

This review specifically focusses on solar E-textiles and their suitability for use in garments. As such key textile properties (bend, stretch, twist, shear, drape, appearance, softness, breathability, moisture transfer characteristics, heat transfer characteristics) and durability considerations for textiles (repeated bending cycles, repeated stretching cycles, repeated twisting cycles, wash resistance, water compatibility, sweat resistance, abrasion resistance) were the key focus. Power densities will also be discussed, as this is critical to understanding the viability of a photovoltaic textiles for a given application, and the long-term stability of the PV devices will also be reported given the limited lifetimes of some designs. The review has primarily looked at the academic literature with other sources only included to give the reader a comprehensive understanding of the area. To the knowledge of the authors this review captures all significant and closely relevant articles as of mid-2019.

To offer a holistic view of the current state-of-the-art for textile energy solutions, Section 2 briefly discusses textile energy storage and Section 3 provides an overview of other forms of textile energy harvesting. Section 4 introduces solar energy harvesting and provides important background necessary for understanding the review of the solar energy harvesting textiles, including an overview of solar cell types.

Currently a variety of different methodologies have been employed to integrate solar energy harvesting capability into textiles for wearable applications [13-17]. These approaches can be categorized based on either their physical structure or the photovoltaic material type. As this review is focused on the practical considerations for a wearable device the following sections will be categorized based on the construction method and architecture used for the solar E-textile. Section 5 will focus on attaching flexible solar panels onto textiles, Section 6 will discuss solar cell arrays, Section 7 will cover the application of flexible photovoltaic films and coatings onto planar textiles, Section 8 will discuss one dimensional photovoltaic structures (such as wires, fibers, and yarns), Section 9 covers textiles woven from photovoltaic fibers, and, finally, Section 10 will cover non-woven photovoltaic textiles. The final section will discuss and overview the extant photovoltaic textiles with a view to their comfort and wearability, their suitability for use with E-textile sensing systems, and offer a future perspective for this area.

\section{Energy Storage Textiles}

Battery technology is well developed and the most widely used method of supplying power to wearable devices. Most commercially available wearable systems are powered by standard solid coin cells, pouch cells, cylindrical cells, or prismatic cell batteries of an Alkaline, NiMH, Li-Ion or Lithium-Ion Polymer (LiPo) type [18]. For E-textiles, these batteries are typically attached to the surface of a garment after assembly, or embedded in a removable module, making the systems bulky and cumbersome to use [9]. Supercapacitors have also been explored for energy storage in textiles however their relatively low energy densities (compared to batteries), and high self-discharge rates limit their utility to secondary energy storage devices or for use in power regulation electronics [9].

While advancements in technology have resulted in both thin and flexible energy storage devices, attaching such devices onto a textile fabric will still have a significant impact on their textile properties, especially their heat and moisture transfer characteristics. As such, significant research has been undertaken to integrate energy storage capability within textiles, and to fabricate textile-based energy storage devices.

Both textile batteries and supercapacitor systems $[8,9,19,20]$ have been developed with an aim to improve the appearance and comfort of the energy storage system for the wearer. Textiles and clothing provide an ideal substrate for integrating energy storage capabilities due to their relatively large 
surface area. Most research to date has focused on textile supercapacitors, with the first example being developed in Stanford University where a textile electrode coated in a single wall carbon nanotube ink was used to create a textile supercapacitor device [21]. Textile-based energy storage devices were reported to be superior to their polymer film and paper based counterparts, due to their flexibility and pliable nature, which prevents kinking, and their ability to recover their shape [22]. An alternative concept is to create a yarn-based supercapacitor, as first demonstrated by Bae et al. in 2011 [23].

Research has also been conducted into the creation of hybrid textile energy systems, where both energy storage and energy harvesting capabilities are combined [24], initially demonstrated by Fu et al. in 2013 where a fiber supercapacitor was combined with a triboelectric generator to allow for the energy generated from body movements to be harvested and stored [25]. This device was formed around a stainless-steel wire. Another example is a flexible ribbon with an organic photovoltaic face and flexible supercapacitor backing, which could simultaneously harvest solar energy and store electricity [26]. These ribbons were subsequently woven into a fabric. Many works regarding hybrid textile energy systems have emphasized the use of supercapacitors to either regulate the energy harvested or to store the harvested energy to minimize the frequency of recharging.

While textile energy storage remains at the forefront of research in the field of wearable energy solutions, many devices have poor durability, washability, appearance, and comfort. In addition, any devices containing corrosive liquid electrolytes pose significant safety concerns [8], this may prohibit their use in wearables.

\section{Textile Energy Harvesting}

Textile energy harvesting is an alternative or complimentary solution to energy storage systems for powering wearables and E-textiles. Energy harvesting systems collect, or harvest, ambient energy from the wearer or surroundings with thermal energy from the human body, kinetic energy due to body movements, wind energy (energy is harvested from wind that caused the fabric to move), and solar energy (photovoltaic conversion of sunlight into electricity) being amongst the most widely investigated sources of energy for wearable systems [27].

\subsection{Thermal Energy Harvesting for Powering Wearables}

Thermal energy can be harvested from the wearer using a thermoelectric (TE) generator. These generators are semiconductor devices that generate an electric current when exposed to a temperature gradient between two surfaces (via the Seebeck effect). Electrical energy can therefore be harvested by taking advantage of the temperature gradient between the human body and environment, with the electrical power generated being dependent on this temperature gradient. This means that the greater the temperature difference between the wearer's skin and the environment, the more energy that can be harvested. The literature reports a number of attempts to develop wearable thermoelectric generators [28-37].

The method employed by Leonov [35] was to attach rigid thermopiles onto a textile (for example a shirt), while Seeberg et al. [36] and Kim et al. [37] realized textile based TE generator systems by using screen-printing techniques on textile substrates (woven cotton and a glass fabric, respectively). Kim et al. reported the resulting TE generator to be both lightweight and flexible.

Moreover, it is to be noted that to achieve power conversion efficiencies greater than $1 \%$, the devices need to be exposed to temperature gradients in excess of $20 \mathrm{~K}$ which are not practical for most wearable applications. For example, the TE generator system by Kim et al. had a power density of $38 \mathrm{Wm}^{-2}$ but only with a temperature gradient of $50 \mathrm{~K}$ [37].

Typically TE generators, including for wearable applications, are fabricated using conventional thermo-electric materials such as $\mathrm{Bi}_{2} \mathrm{Te}_{3}$ and $\mathrm{PbTe}$ which are brittle, toxic, heavy, and therefore undesirable to use for wearable applications [1,29]. While flexible TE generators can be achieved these do not exhibit other typical textile properties such as breathability, or drape. This will affect the comfort of the wearer when using the device. 
An alternative means of harvesting thermal energy are pyroelectric generators which rely on temperature fluctuations (change in temperature over time) caused by thermal diffusion [38]; however, low levels of skin temperature fluctuation make this technology unsuitable for wearable applications [29].

\subsection{Piezoelectric Generators for Powering Wearables}

Piezoelectric generators can be used to harvest energy from human motion. These generators incorporate a piezoelectric material which will generate an electron flow when subjected to mechanical strain by either being compressed or tensioned. For wearable applications, piezoelectric generators are typically fixed onto regions on the body where large dynamic compressive forces (directly compressing the material) or tensile forces (indirectly stretching strands of the fibers) due to motion are generated.

A number of textile based piezoelectric generators have been reported in the literature [39-49]. Different types of piezoelectric strands have been produced by wrapping or twisting piezoelectric fibers, nanofibers or yarns, and through different fiber spinning techniques, such as electrospinning and melt spinning a bi-component fiber made with a poly(vinylidene fluoride) sheath and a conductive high density polyethylene/carbon black core. These piezoelectric fibers and strands have also been converted into textiles leading to woven, knitted, braided, non-woven, and spacer fabric structures $[46,48,49]$, which may offer useful textile energy harvesting solutions. One of the highest reported power densities for piezoelectric fabrics was reported by Qin et al. for a twisted microfiber- $\mathrm{TiO}_{2}$ nanowire hybrid yarn where a power density of $80 \mathrm{~mW} / \mathrm{m}^{-2}$ was achieved [50].

\subsection{Triboelectric Generators for Powering Wearables}

The triboelectric effect sees a material become electrically charged after it is separated from another material; contact-induced build-up of static electricity is an example of the triboelectric effect. The contact and separation between the materials can occur in a number of ways (i.e., sliding) and triboelectric generators can be used to harness energy from vibrations or frictional forces generated by either human motion or the wind. Triboelectric generators can generate high power densities, and high voltages of up to $1200 \mathrm{~V}$ [51]. These high power densities are instantaneous, generating a high electrical potential difference between the triboelectric surfaces with small pulses of current. A variety of textile and wearable triboelectric nano-generators have been reported in the literature in recent years [52-61], with power densities as high as $500 \mathrm{~W} / \mathrm{m}^{2}$ being reported [61].

Despite the high voltages and power densities achievable with triboelectric generators, these systems are highly volatile and the total energy generated over a time interval is unpredictable. Although the Triboelectric generators have some inherent energy storage capability in the form of dielectric capacitors $[62,63]$ this internal capacitance is not sufficient to regulate the power output. Therefore, triboelectric generators require sophisticated energy management systems to convert and regulate the power before being used to power devices [64].

\subsection{Electromagnetic Induction-Based Energy Harvesters for Powering Wearables}

Electromagnetic induction occurs when a conductive coil is placed within a varying magnetic field generating an electric current in the coil, and therefore this technique can be used to harvest energy from motion. Electromagnetic induction has been investigated for powering wearable devices [65-69], especially for shoes. An electromagnetic induction-based energy harvester normally has a permanent magnet at its core which is free to move inside of a tubular structure onto which conductive induction coils are mounted. The reported textile-based devices of this kind are typically heavy, rigid and bulky - this makes them unsuitable for most textile-based solutions. As with piezoelectric generators and triboelectric generators, the power output of electromagnetic inductors is dependent on motion and can therefore be inconsistent. 


\section{Solar Energy Harvesting}

Solar energy can be harnessed by irradiating sunlight upon semiconductor materials that can release free electrons in order to generate an electron flow. This effect was first observed by French physicist A. E. Becquerel in 1839, and is defined as the photoelectric effect [70]. A typical solar cell comprises of two semiconductor materials (P-type and N-type) and two electrodes (often referred to as the electrode and counter-electrode), as shown in Figure 1.

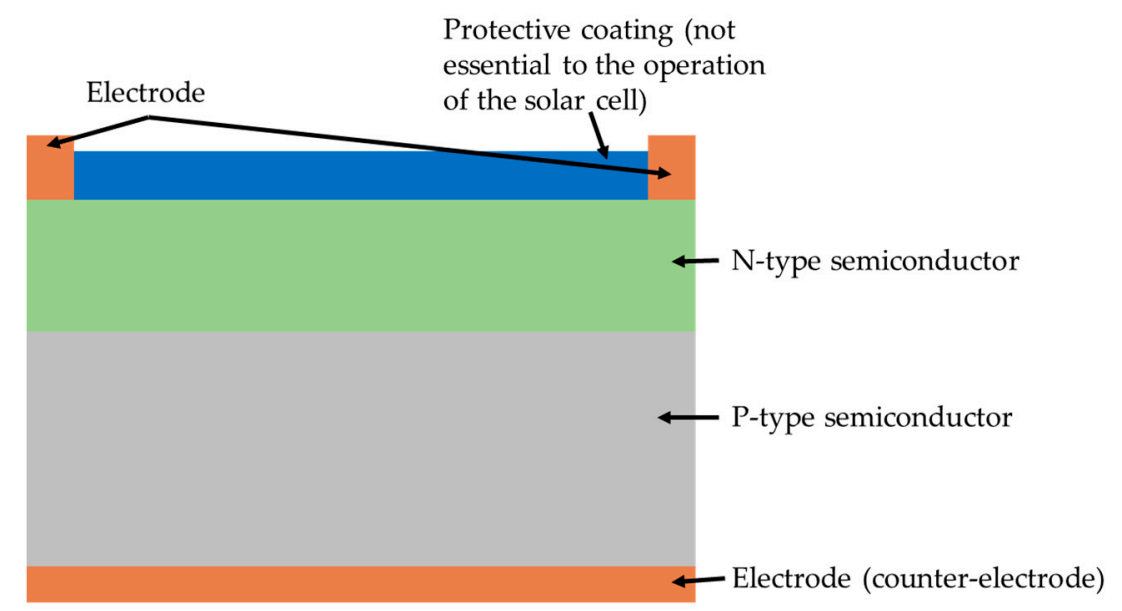

Figure 1. Simple schematic of a typical solar cell comprising of two semiconductor materials (P-type and N-type) and two electrodes.

The energy harvested by a solar cell is typically characterized using two parameters, fill factor (FF) and power conversion efficiency (PCE).

FF is a characteristic parameter for a given cell type and indicates the performance of the cell when the maximum power is drawn. It is defined by Equation (1) below.

$$
\mathrm{FF}=\frac{V_{M P} \times I_{M P}}{V_{O C} \times I_{S C}}
$$

where $V_{M P}$ and $I_{M P}$ are the maximum voltage generated and maximum current generated (respectively) at the point where the maximum power $\left(P_{M A X}\right)$ is generated. $V_{O C}$ (the open circuit voltage) is the voltage across the solar cell when no connection is made between the terminals (zero current is drawn from the cell), which is the maximum possible voltage. $I_{S C}$ is the short circuit current which represents the current flow through a zero-resistance conductor when connected between the terminals of the solar cell, which is the maximum possible current. A current-voltage characteristic curve showing the behavior of a solar cell is shown in Figure 2. 


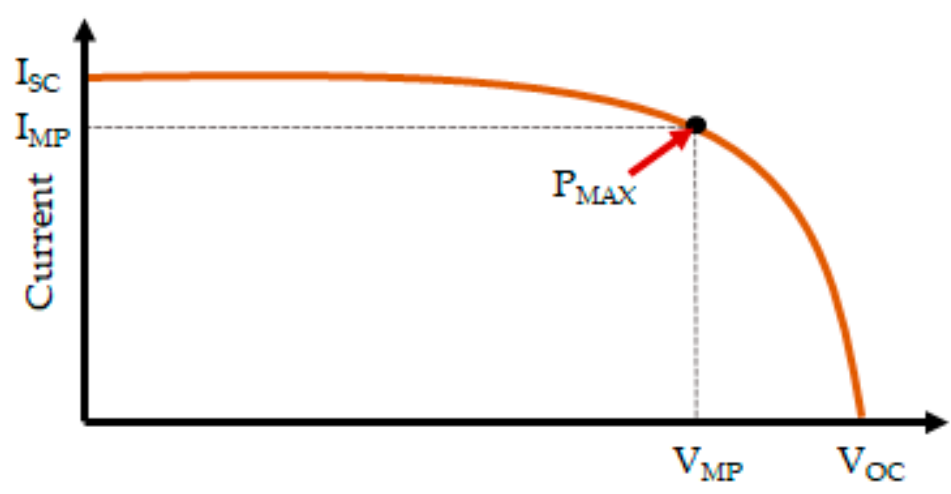

Figure 2. Diagram showing a typical current-voltage curve for a solar cell. The point where the maximum power is achieved has been annotated on the figure. This figure has been drawn and is not generated from collected data.

The power conversion efficiency (PCE) of a solar cell is the percentage of the incident light energy reaching the solar cell $\left(P_{I N}\right)$ converted into electric energy by the solar cell (Equation (2)).

$$
\mathrm{PCE}=\frac{V_{M P} * I_{M P}}{P_{I N}} \times 100 \%=\frac{F F * V_{O C} * I_{S C}}{P_{I N}} \times 100 \%
$$

Both the FF and PCE will be dependent on the type of semiconductor used in the solar cell.

Solar cells can be categorized into three generations, mainly based on semiconductor material combinations. The first generation of solar cells were the mono-crystalline/multi-crystalline single junction type, such as the crystalline silicon (c-Si) solar cell, which still dominates the market today. First-generation solar cells are typically rigid and brittle, and therefore need to be mounted on rigid frames to protect the cells from breaking. Second-generation solar cells were produced as thin films to reduce manufacturing costs [71], with the trade-off being lower efficiency levels compared to single crystal types (with the exception of more expensive gallium arsenide (GaAs) cells). The third-generation of solar cell technologies include multi-junction cells, organic photovoltaic (OPV) cells, and hybrid solar cells. Hybrid solar cells, namely dye-sensitized solar cells (DSSC) and perovskite solar cells, employ inorganic and organic semiconductor material combinations. Most of these third-generation cell types are yet to make a significant entry into large scale commercial applications due to the challenges faced in scaling up of production, durability, or cost. Despite this, multi-junction solar cells have successfully managed to enter extra-terrestrial and concentrated photovoltaics markets due to their unparalleled conversion efficiencies (PCE $=38.8 \pm 1.2 \%$ [72]); however, their volumes remain small due to their high cost. In recent years, the organic and hybrid cell concepts have shown great promise in achieving improvements in conversion efficiency and durability, especially for application demanding mechanical flexibility [71].

\section{Integrating Flexible Solar Panels with Textiles}

The simplest method of adding solar energy harvesting capability to a textile is to superficially attach flexible solar panels onto the surface of a fabric: This method has been employed to develop many consumer products [14,73], including a plethora of solar backpacks available on the market. This includes the Kingstons Beam Backpack (Kingstons, Guangzhou, China) which has an integrated flexible thin film copper indium gallium selenide (CIGS) solar cell on its outer surface (produced by MiaSolé, Santa Clara, CA, USA) [74] with a conversion efficiency of $19.2 \%$ [75]. Similarly the Zenith Solar Backpack (by Sunslice) uses a flexible CIGS solar panel (with a 15\% PCE) attached to the backpack's outer face [76]. The use of CIGS cells for these products is likely due to the flexibility that can be achieved when fabricated on a plastic backing and their reasonable power conversion 
efficiencies. It should be noted that most CIGS are produced using a glass substrate, in which case these cells would not be flexible.

Flexible solar panels have also been attached onto the surface of apparel and early examples include the Maier Sports' prototype of a winter outdoor jacket, which was first presented in Munich at the International Trade Fair for Sports Equipment and Fashion 2006. The jacket incorporated nine amorphous Si solar modules from AkzoNobel (Amsterdam, Netherlands) and could generate a $P_{M A X}$ of $2.5 \mathrm{~W}$ under full sun conditions [13]. Amorphous silicon (a-Si) is an alternative thin film solar cell technology which can achieve flexibility by creating the solar cells using a flexible substrate. It is unclear from the available literature whether the solar cells used for this jacket were definitely flexible, however it seems likely as if flexibility was not desired c-Si cells would have likely been used to achieve a higher PCE. Tommy Hilfiger's solar powered jacket from 2014 used a similar concept [77], and comprised flexible amorphous silicon solar cells developed by Pvilion (New York, NY, USA); these solar cells were flexible [78]. The fashion designer and researcher Pauline van Dongen developed a collection of designer wear where thin film solar cells were attached onto garments [79-81] including: the 'Wearable Solar Dress' from 2013, 'The Solar Shirt' from 2014 which can generate $1 \mathrm{~W}$ under direct sunlight; the wearable solar dress, also from 2014; 'The Solar Parka' from 2015; 'The Solar Windbreaker' from 2016. The 'Wearable Solar Dress' and' The Solar Shirt' both utilized flexible solar cells of an unreported type [81]. These cells were flexible, but not foldable, so multiple separate solar cells were incorporated into the garment, as opposed to a single large cell, to allow for greater movement between the cells. Despite this the 'Solar Dress' was reported to limit movement and the wiring could be felt. 'The Solar Shirt' used printed electronic interconnections between the cells, and the garment was reported as being more flexible.

Garments with attached flexible solar cells effect the appearance, and may affect the comfort of the wearer, which will likely limit their application to outerwear and futuristic fashion prototypes. While solar cells can be made water compatible it is unknown how garments made using flexible solar cells attached to the surface would cope with the relatively severe conditions of a domestic machine wash. In order to achieve satisfactory levels of wearability (softness and comfort) and washability, conformal (drapeable and shear deformable) PV devices with the structural (hierarchical and porous) features inherent to a textile structure are necessary.

\section{Solar Cell Arrays}

A similar concept to attaching flexible solar cells onto textiles is to exploit rigid inorganic semiconductor PV materials by mechanically and electrically linking the inorganic solar cells together with flexible materials to create quasi-flexible structures. A number of such embodiments for wearable applications have been proposed in patents and patent applications in the form of solar jackets or suites [82-84], non-garment based solar textiles [85-90], and more generally flexible interconnected solar cell networks based on fabrics [91-97]. The products and processes disclosed in these patents appear to be of limited use for practical wearable systems, due to an inadequate level of flexibility, lack of shear behaviour, and unsuitability for machine washing. In addition, the appearance rendered by these fabric attached devices were not desirable for the use on regular clothing. However, without examples of completed textiles, it is difficult to conclusively comment on these concepts.

Sandia National Laboratories have worked with micro-scale inorganic photovoltaic cells for concentrator photovoltaic applications, which were also explored for flexible solar arrays as reported in 2011 [98] (see Figure 3). This PV technology has been demonstrated in flexible moldable concentrator PV arrays, as shown in 2015 [99], as well as flexible arrays of closely packed cell arrays mounted on a flexible substrate as shown in 2017 [100]. The bespoke small-scale PV cells have a hexagonal shape, with back contacts, and typically have a thickness of $14 \mu \mathrm{m}$ and a width from 250-500 $\mu \mathrm{m}$. With an optimized cell design a PCE of $14.9 \%$ has been achieved. This innovation, while potentially useful for E-textile applications, has not been presented for this use. As a result information on other properties that would be needed for a wearable E-textile is not present in the literature; however, given the dense 
structure of the solar cell array if worn, the array would not provide the wearer with a normal textile feel as the array is not porous or soft, and lacks a normal textile appearance. It is unclear if the array would be sufficiently durable to survive machine washing.
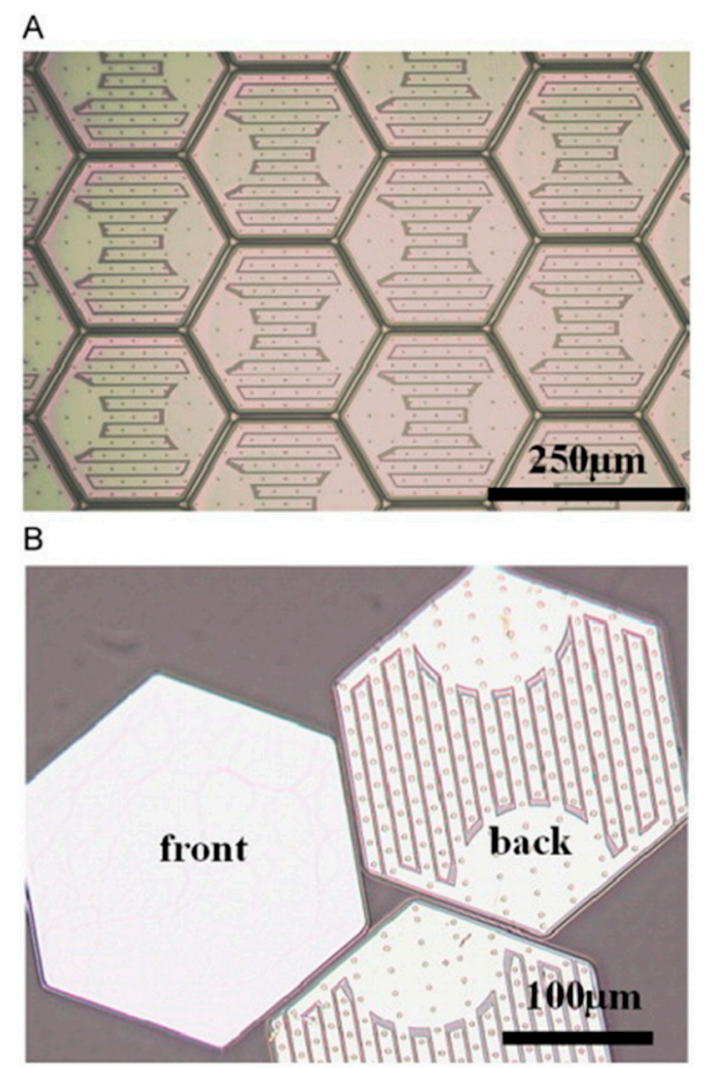

Figure 3. Microscope image of micro-structured PV cells developed by Sandia Laboratories. Reprinted from [98] with permission from Elsevier. (A) An array of cells attached to the wafer (B) The front and back the cells.

In 2019, researchers in the Advanced Textiles Research Group at Nottingham Trent Unviersity demonstrated a method of embedding arrays of small-scale solar cells $(1.5 \mathrm{~mm} \times 3.0 \mathrm{~mm} \times 0.2 \mathrm{~mm})$ within textile yarns, which were subsequently woven into fabrics (Figure 4). The rigid solar cells were linked using flexible copper wires producing fabrics with normal textile properties. This design has been shown to be bendable, can undergo shear deformation, and is drapeable; however, these characteristics have not been fully quantified in the literature. Fabrics were also wash tested using standard domestic laundering and retained $\sim 90 \%$ of their original power output after 15 machine wash cycles. A PV fabric with a $44.5 \mathrm{~mm} \times 45.5 \mathrm{~mm}$ active area generated $\sim 2.15 \mathrm{~mW} / \mathrm{cm}^{2}$ under one sun illumination (2.15\% PCE), which was demonstrated to charge a mobile phone and fitness tracker [101]. Compatibility with water was also demonstated. The funtionality of the solar cell embedded fabrics after 6000 abrasion cycles showed a $5.6 \%$ reduction in $I_{S C}$. 


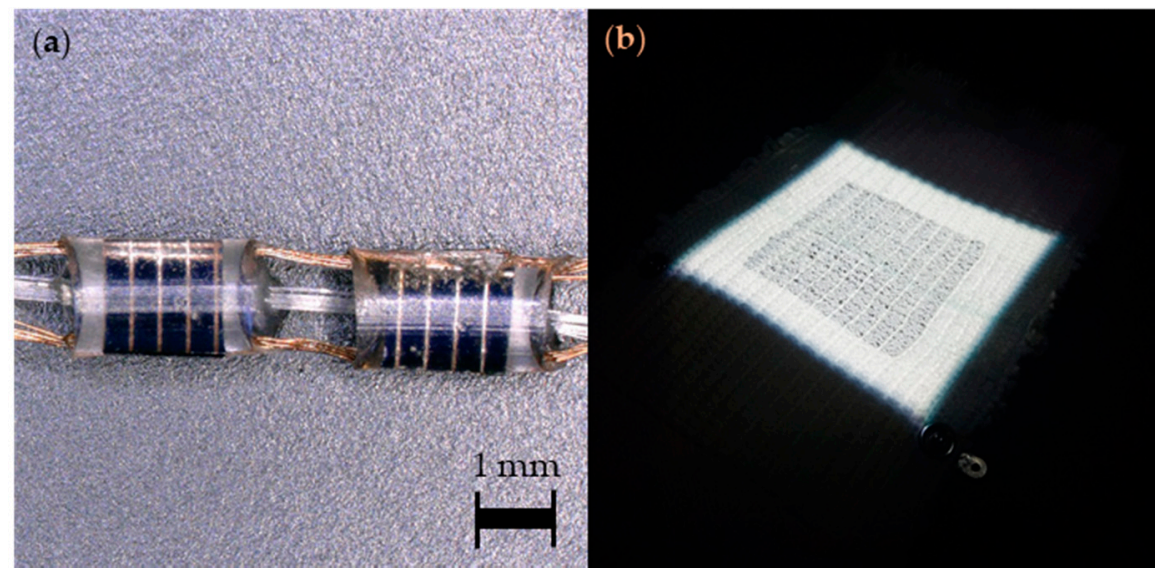

Figure 4. (a) Rigid solar cells soldered onto flexible copper wires. The filaments would subsquently be covered with textile fibers. (b) A woven solar fabric.

\section{Applying Flexible Photovoltaic Films and Coatings onto Planar Textiles}

Printing, laminating or coating [102] organic photovoltaics (OPV) [103-105], hybrid photovoltaics (such as DSSCs [106,107] and perovskite solar cells [108,109]) onto planar textiles has been widely investigated for textile-based PVs (an example of a film-based textile OPV is shown in Figure 5).

a

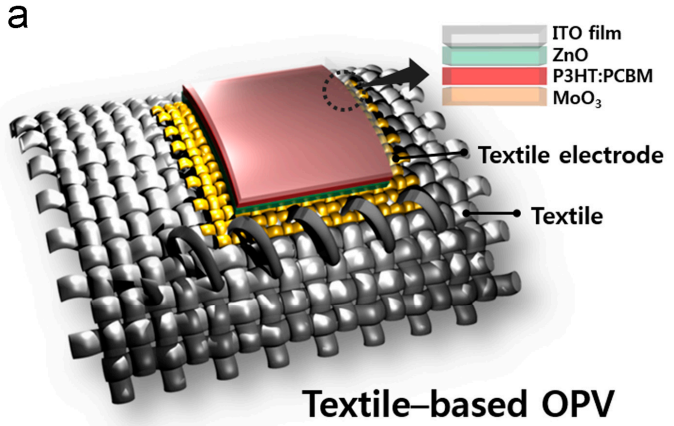

b

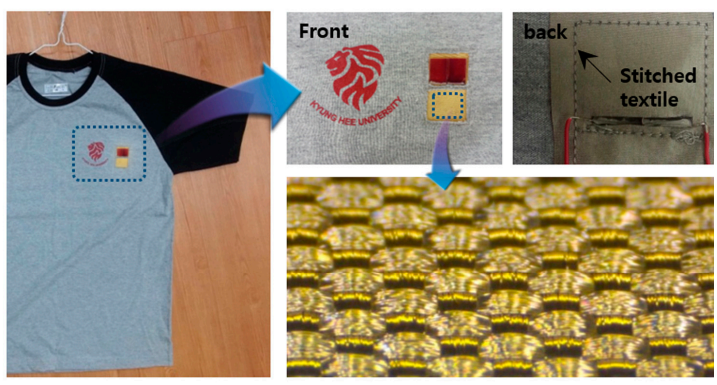

Figure 5. A textile based OPV developed by Lee et al. Reprinted from [105] with permission from Elsevier. (a) Schematic illustration of the textile OPV. (b) Photographs of the textile OPV integrated with clothing.

\subsection{Organic Photovoltaic Films and Coatings}

In 2006 Krebs et al. [103] reported one of the first printed PVs intended for use with textile fabrics. Here, organic photovoltaic devices were fabricated onto non-transparent polyethylene terephthalate (PET) or Polyethylene (PE) tapes, where two strategies of fabric integration were explored. The first method saw the PET tapes coated with organic PV materials before being laminated on to a suitably transparent textile fabric, which resulted in a somewhat stiff device. In the second method, PE tapes were first laminated onto the fabric prior to the application of the PV coatings and electrodes, making a more flexible device. The PCE of these textile coated PVs was $1.4 \times 10^{-3} \%$, and they had a fill factor of $25 \%$. A substantial degradation in this performance was observed within two hours of direct exposure to light (one Sun intensity), which was mainly attributed to the instability of photovoltaic material under sunlight. Similar work was presented by Bedeloglu et al. in 2009 [110], where polymer PV coatings were used on six different substrates (polypropylene based and ITO/glass based). A maximum PCE of $\sim 0.37 \%$ was achieved for the ITO/glass-based substrate. Bedeloglu et al. also realized a $0.33 \%$ PCE for a flexible nano-silver coated polypropylene (PP) tape that could be laminated onto textiles.

In order to make flexible PV films more compliant for wearable applications, in 2011, Lipomi et al. [111] devised a stretchable polymer solar cell by spin coating a pre-strained polydimethyl 
siloxsane (PDMS) film with polymeric PV materials. These stretchable films achieved a PCE of $2 \%$. These devices were tested under different levels of mechanical loading (stretching), observing that the PV characteristics of the devices had little dependency on the strain applied. This strategy of coating pre-strained PDMS, or similar elastic films, was adopted widely in subsequent studies to achieve stretchable PV films. In 2012, Kaltenbrunner et al. prepared thin polymer PV films on PET foils which exhibited a PCE of 4\% [112]. It was possible to attach these thin films onto pre-stretched elastomeric films to realize flexible, stretchable PV films. The films exhibited three-diamentional deformability (as demonstrated in Figure 6). Pre-stretched films were tested under extreme mechanical deformation, being compressed by $80 \%$ and still functioning (alblight with the PCE reducing to 0.25 of its intial value), and showing no deterioration in performance when re-stretched. Cyclic compression and stretching tests to $50 \%$ compression were also shown, with a PCE of $73 \%$ being maintained after 22 cycles.

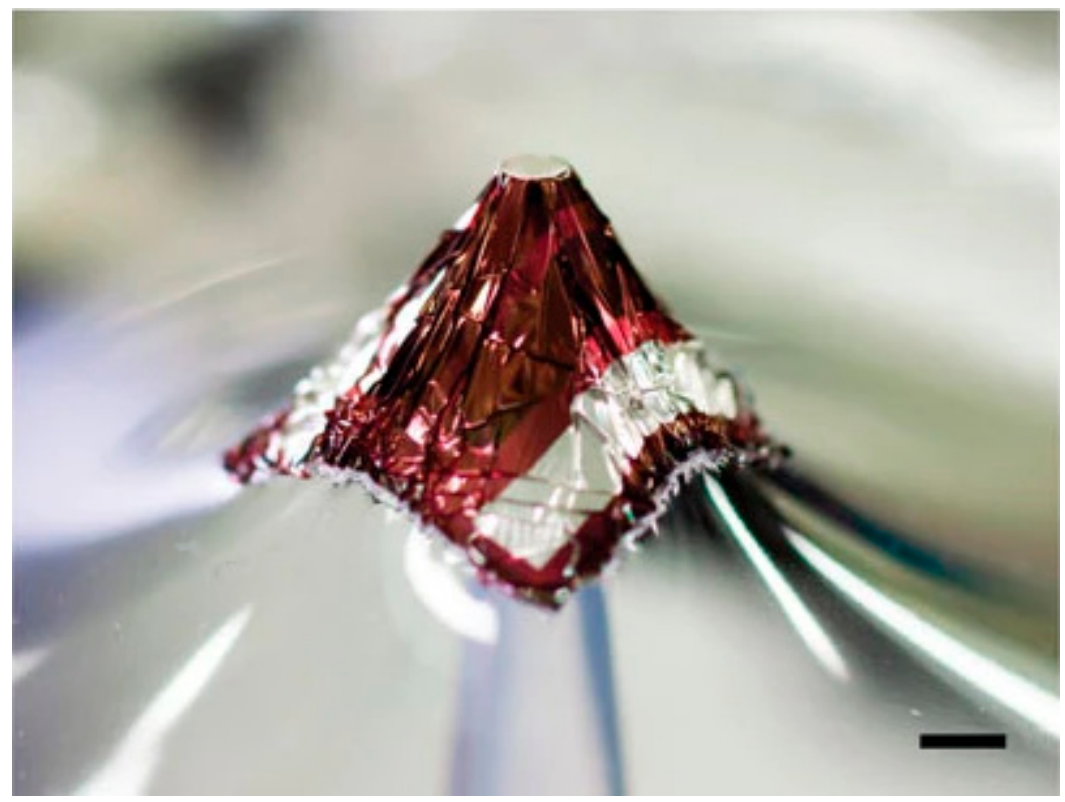

Figure 6. The thin polymer PET foil based solar cell attatched to an elastomeric support developed by Kaltenbrunner et al. This image shows the three-diamentional deformablity of the structure when deformed by applying pressure from a $1.5 \mathrm{~mm}$ diameter tube. Taken from [112]; this image is licensed under a Creative Commons Attribution-NonCommercial-Share Alike 3.0 Unported License.

Kylberg et al. developed organic PV coatings on woven structures that were made with a combination of metal and polymeric mono-filaments in 2010 [113]. One side of the woven structure was coated with a transparent PET filler material (this side was used as the active side of the cell), with the back electrodes coated on the other side of the woven structure. This construction resulted in a flexible polymeric film with a PCE of $2.2 \%$.

An organic photovoltaic cell where a fabric electrode was prepared by weaving PE multifilament yarns coated with conductive metal multilayers was proposed in 2014 [105] (shown in Figure 5). The authors presented a construction where at least part of the solar cell was a textile structure. This OPV could be stitched and was integrated onto a T-shirt. These solar cells had a PCE of $1.8 \%$.

In 2016, Arumugam et al. realized a fully spray coated OPV on a polyester cotton blended plain woven fabric by smoothening the fabric surface using a screen printed interface layer [114]. This construction only yielded a PCE of $0.02 \%$. While flexible, bending and cyclic bending tests resulted in the devices losing their functionality.

An organic PV film was presented by Jinno et al. in 2017 which exhibited a high PCE of 7.9\% [104]. The film was developed for wearable applications and was both waterproof and washable. The devices 
were stretchable and flexible. Images of the device show that it was highly deformable and may exhibit drape characteristic (however, this was not claimed by the authors). Both compression and cyclic compression were examined, with the (single side coated) device retaining $99 \%$ of its original PCE after 20 cycles at $43 \%$ compression. The washability of the OPV film was demonstrated by placing the OPV in a detergent-water mix which was stirred for $5 \mathrm{~min}$. Various experiments were conducted to demonstrate the water stability of the device. To improve compatibility with water and achieve stretchability, the OPV film was sandwiched between two layers of stretched acrylic elastomer. Further tests were conducted by dipping both the OPV film and sandwiched devices into distilled water for $120 \mathrm{~min}$, which showed $\sim 20 \%$ and $\sim 5 \%$ reductions in PCE, respectively. The PCE of the device was reported to reduce by $46 \%$ after $1000 \mathrm{~h}$.

A study on textile OPVs from 2019 used a $\mathrm{SiO}_{2}$-polymer composite capping-layer as a protective encapsulation [115]. The wash durability of these OPV devices was tested by stirring them in $2 \%$ detergent solution inside of a beaker for $10 \mathrm{~min}$ after subjecting the device to 1000 bending cycles ( $3 \mathrm{~mm}$ bend radius). This test was repeated up to 20 times for thirty days and the OPV devices showed no significant change in performance after this time. These devices also generated an impressive PCE of $7.26 \%$. This construction, however, was not stretchable, although it could undergo thousands of bending cycles without a deterioration in performance.

\subsection{Dye Sensitized Solar Cell Films and Coatings}

One of the first studies on textile based DSSCs was presented by Du et al. in 2013 [102] who created DSSCs with an iodide/triiodide (I-/I3-) electrolyte (liquid electrolyte); these flexible devices demonstrated a PCE of 3.93\%; however, their long-term stability was not evaluated. A flexible cotton fabric based DSSC was presented in 2014 by Xu et al. and yielded a PCE of 3.3\% [116]. This flexible device used a liquid electrolyte. The PCE was further enhanced up to $3.83 \%$ by the same research team in 2016 [117].

Yun et al. prepared DSSCs on metal wire woven structures, without using transparent conducting oxides, and a liquid electrolyte in 2016, which generated a PCE of 4.16\% [118]. This flexible device was tested when bent at different radiuses of curvature and was seen to maintain $80 \%$ of its performance after 2000 bending cycles. The same year Opwis et al. realized a flexible DSSC on a polyamide-coated glass woven fabric where a liquid electrolyte was used, which generated a PCE of 1.1\% [119] (see Figure 7); these had a stable performance for at least seven weeks and showed improved efficiency at lower incident light intensities. The study also reported the performance of the DSSC at different operating temperatures.

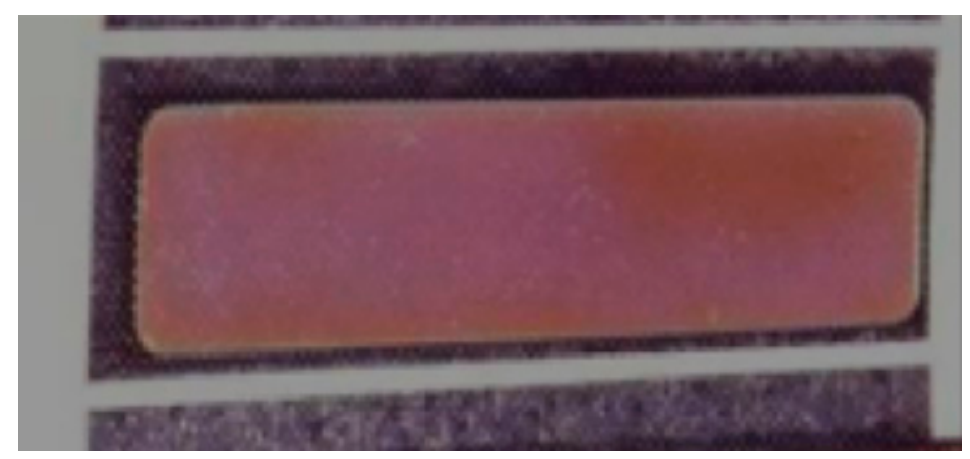

Figure 7. Photograph of a textile-based dye sensitized solar cell developed by Opwis et al. Adapted from [119]; this image is licensed under a Creative Commons Attribution 4.0 International License (CC BY 4.0).

A DSSC was developed on woven polyester cotton blended fabric by Liu et al. in 2018, by screen printing an interface layer onto the fabric before coating it with a silver electrode, with the resultant DSSCs exhibiting a PCE of 2.78\% [106]. This approach was similar to how Arumugam et al. prepared 
the fully spray coated textile based OPVs [114]. This device was not flexible, using a rigid platinum coated FTO glass for one electrode. A liquid electrolyte was used with this design. In 2019, Yun et al. developed a textile DSSC based on a three-dimensional structure where an electrolyte-infused woven glass-fiber spacer fabric was sandwiched between two stainless steel woven fabric electrodes coated with active materials [120] (see Figure 8). The final structure was encased inside of a polyester film pouch which was filled with a liquid electrolyte. This design of textile DSSC generated a PCE of $1.7 \%$. The devices were tested when bent to different radiuses of curvature proving its flexibility. Cyclic bending tests demonstrated a reduction in efficiency of $40 \%$ after 1000 bending cycles, with no further reduction observed after 2000 bend cycles. By using a non-volatile electrolyte, the DSSC saw a slight increase in specific power after one day, with specific power remained stable for the following six days.

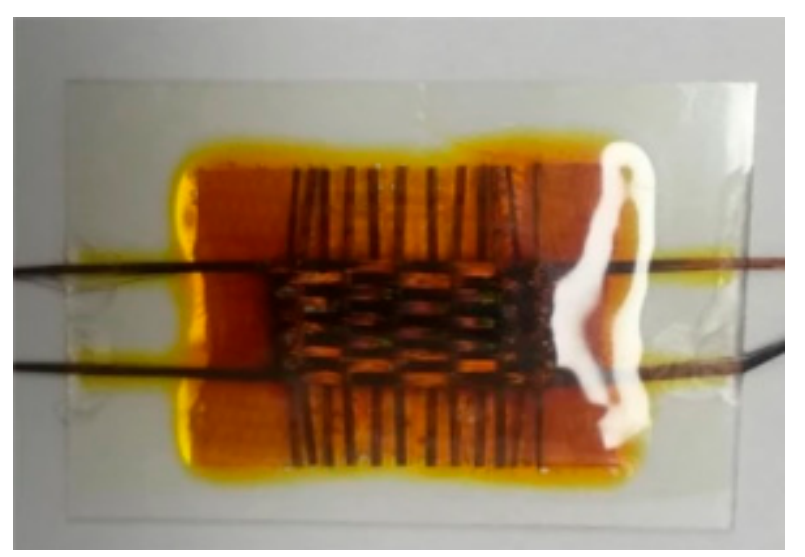

Figure 8. 3D textile DSSC developed by Yun et al. Adapted from [120]; this image is licensed under a Creative Commons Attribution 4.0 International License (CC BY 4.0).

Building on work from 2017 [121], in 2019, Song et al. reported a flexible DSSC photovoltaic textile, created using a quasi-solid electrolyte, with a power conversion efficiency of $5.08 \%$ that was achieved by attaching a DSSC film onto a textile using an epoxy [122]. The work demonstrated counter-electrode designs that could be twisted, had good mechanical strength, and that could be bent multiple times, leading to a final DSSC textile that was flexible.

\subsection{Other Types of Solar Cell Films and Coatings}

Solar energy harvesting textiles using other types of coating or film technology have also been developed.

A flexible CIGS thin film coating was presented on glass-fiber-woven fabrics by Knittel et al. in 2009 (shown in Figure 9), which achieved an efficency of 8.0\% [123].

A hydrogenated amorphous Si thin-film solar cell was prepared on a glass fiber fabric by Plentz et al. in 2016. The device (see Figure 10) realized a PCE of 1.41\%; however, this approach was not suitable for applying PV functionality directly onto standard textiles substrates such as PA or PET due to the high processing temperatures necessary [124].

In 2017 Lam et al. reported a flexible textile-based perovskite PV laminate using a $\mathrm{SnO}_{2} / \mathrm{PCBM}$ active layer and an elastomeric encapsulation covering the fabric and active layers, which demonstrated a PCE of $15 \%$ [108]. The work claimed that the ductility of the encapsulating elastomer provided good flexibility and the potential for washability; however, experimental evidence to prove these claims was not presented. The stabilty of the device was evaluated seeing that it was able to maintain $70 \%$ of its initial PCE after $425 \mathrm{~h}$. Water compatability was also shown, with the device showing little deterioration in performance after $35 \mathrm{~min}$ submerged in water. 


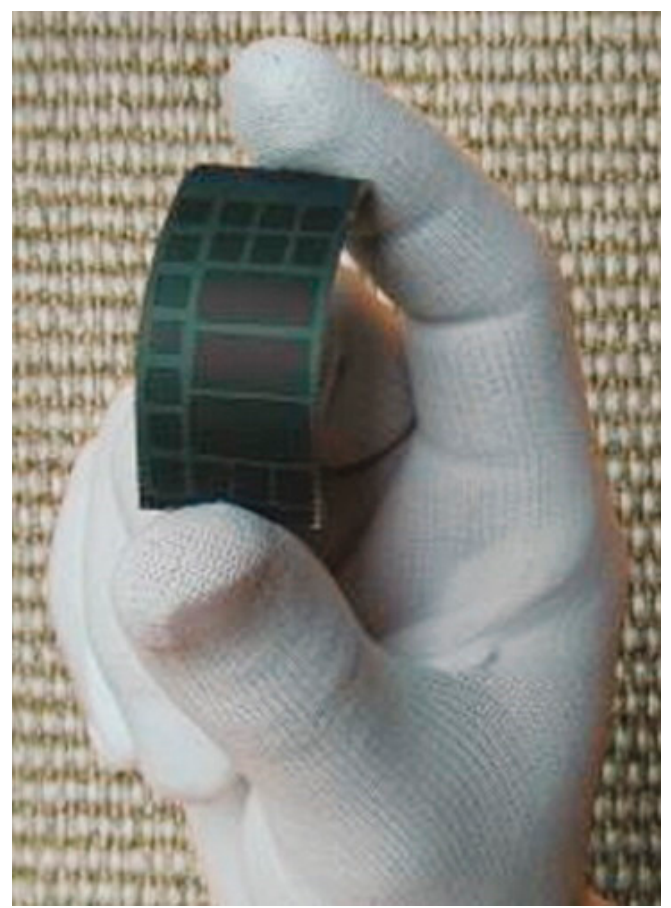

Figure 9. Photograph of the flexible copper indium gallium selenide thin film solar cell on glass fabric developed by Knittel et al. Reprinted from [123] with permission from Wiley.

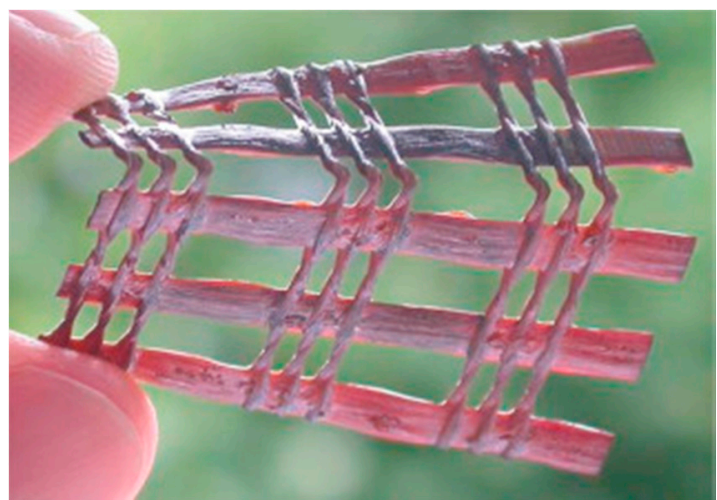

Figure 10. Thin film solar cell on glass fiber fabric developed by Plentz et al. Reprinted from [124] with permission from Elsevier.

In 2018, Jung et al. reported flexible perovskite solar cells where a polyurethane coating on the textile fabric enabled low-temperature solution processing, resulting in solar cells that achieved a PCE of 5.7\% [109]. The device maintained 83\% of its PCE after $300 \mathrm{~h}$.

\subsection{Discussion of PV Films and Coating Applied to Textiles}

The key information regarding photovoltatic films and coatings applied to textiles are summarised in Table 1. 
Table 1. Summary of key information regarding the reported properites of various photovoltatic films and coatings used on textiles. Please note that PCE (\%) are the values given and do not account for any differences in how the PCE may have been calculated between works. 'Likely flexible' has been stated when the flexability of the device is not explictily commented upon or shown.

\begin{tabular}{|c|c|c|c|c|c|c|c|}
\hline & Type of SC & $\begin{array}{l}\mathrm{PCE} \\
(\%)\end{array}$ & $\begin{array}{c}\text { Mechanical } \\
\text { Deformability }\end{array}$ & $\begin{array}{l}\text { Mechanical } \\
\text { Durability }\end{array}$ & Washability & Stability & Other \\
\hline Krebs et al. [103] & OPV & 0.0014 & Flexible & & & $\begin{array}{c}\text { Substantial } \\
\text { degradation after } 2 \\
\mathrm{~h}\end{array}$ & \\
\hline Bedeloglu et al. [110] & OPV & 0.33 & Flexible & & & & \\
\hline Lipomi et al. [111] & OPV & 2 & Flexible, stretchable & & & & \\
\hline Kaltenbrunner et al. [112] & OPV & 4 & $\begin{array}{l}\text { Flexible, stretchable, 3D } \\
\text { deformation (drape) }\end{array}$ & $\begin{array}{l}\text { Cyclic compression } \\
\text { tested to } 22 \text { cycles. }\end{array}$ & & & \\
\hline Kylberg et al. [113] & OPV & 2.2 & Flexible & & & & \\
\hline Lee et al. [105] & OPV & 1.8 & Likely flexible & & & & \\
\hline Arumugam et al. [114] & OPV & 0.02 & Flexible & $\begin{array}{l}\text { Bend and cyclic bend } \\
\text { tests led to loss of } \\
\text { functionality. }\end{array}$ & & & \\
\hline Jinno et al. [104] & OPV & 7.9 & Flexible, stretchable & $\begin{array}{l}\text { Cyclic compression } \\
\text { testing to } 20 \text { cycles. }\end{array}$ & $\begin{array}{l}\text { Compatible with } \\
\text { water, washable } \\
\text { under mild } \\
\text { conditions. }\end{array}$ & $\begin{array}{l}46 \% \text { decrease in } \\
\text { PCE after } 1000 \mathrm{~h}\end{array}$ & \\
\hline Jeong et al. [115] & OPV & 7.26 & Flexible & $\begin{array}{l}1000 \text { bend testing } \\
\text { cycles }\end{array}$ & & $\begin{array}{c}\text { No notable } \\
\text { degradation after } \\
30 \text { days. }\end{array}$ & \\
\hline Du et al. [102] & DSSC & 3.93 & Flexible & & & & \\
\hline Xu et al. [116] & DSSC & 3.3 & Flexible & & & & \\
\hline Xu et al. [117] & DSSC & 3.83 & Likely flexible & & & & \\
\hline Yun et al. [118] & DSSC & 4.16 & Flexible & $\begin{array}{l}\text { Bend testing to } 2000 \\
\text { cycles. }\end{array}$ & & & \\
\hline
\end{tabular}


Table 1. Cont.

\begin{tabular}{|c|c|c|c|c|c|c|c|}
\hline & Type of SC & $\begin{array}{l}\text { PCE } \\
(\%)\end{array}$ & $\begin{array}{c}\text { Mechanical } \\
\text { Deformability }\end{array}$ & $\begin{array}{l}\text { Mechanical } \\
\text { Durability }\end{array}$ & Washability & Stability & Other \\
\hline Opwis et al. [119] & DSSC & 1.1 & Flexible & & & $\begin{array}{c}\text { Stable after seven } \\
\text { week. }\end{array}$ & $\begin{array}{l}\text { Performance at } \\
\text { different operating } \\
\text { temperatures } \\
\text { reported. }\end{array}$ \\
\hline Liu et al. [106] & DSSC & 2.78 & & & & & \\
\hline Yun et al. [120] & DSSC & 1.7 & Flexible & $\begin{array}{l}\text { Bend testing to } 2000 \\
\text { cycles. }\end{array}$ & & & \\
\hline Song et al. [122] & DSSC & 5.08 & Flexible & & & & \\
\hline Knittel et al. [123] & CIGS & 8 & Flexible & & & & \\
\hline Plentz et al. [124] & a-Si & 1.41 & Likely flexible & & & & \\
\hline Lam et al. [108] & Perovskite & 15 & Likely flexible & & $\begin{array}{l}\text { Compatible with } \\
\text { water }\end{array}$ & $\begin{array}{l}\text { Maintained } 70 \% \\
\text { initial PCE after } \\
\quad 425 \mathrm{~h}\end{array}$ & \\
\hline Jung et al. [109] & Perovskite & 5.7 & Flexible & & & $\begin{array}{l}\text { Maintained } 83 \% \\
\text { initial PCE after } \\
\quad 300 \mathrm{~h}\end{array}$ & \\
\hline
\end{tabular}


Table 1 clearly shows that flexibility is the property that is most reported, with many works also presenting data testing the PV device after multiple bending cycles. Some stretchable devices have also been demonstrated. The OPV devices by Kaltenbrunner et al. and Jinno et al. were both highly deformable [104,112], with the device by Kaltenbrunner et al. showing 3D deformation (as shown in Figure 6). Only Lam et al. and Jinno et al. demonstrated compatibility with water for their devices [104,108]. Jinno et al. also showed that their device was washable under mild conditions [104]. While the device proposed by Lam et al. was perovskite-based, water compatibility was achieved by using an encapsulation [108]. This also significantly extended the lifetime of the cell under ambient conditions, as a version of the cell without the encapsulation degraded significantly after $100 \mathrm{~h}$ due to Perovskite's instability to moisture and oxygen. The stability of perovskite solar cells is a known limitation to the technology. Stabilities of other devices were largely unreported, however Opwis et al. and Jeong et al. showed that their devices had good stability over many weeks [115,119]. The PCE of the reported devices ranged significantly with OPV devices with a maximum PCE of 7.9\% [104], DSSCs with a maximum PCE of 5.08\% [122], and Perovskite-based cells with a PCE as high as 15\% presented [108].

Without further testing and details on durabilty, it is difficult to fully comment on the suitabilty of these materials for textile garment applications. The general suitabilty of these devices may be limited by two factors. These PV systems significantly alter the color and fibrous surface morphology of textile fabrics. For example, most PV films have a smooth glossy surface with a rubbery or foil-like texture, and the colors are typically limited to the inherent colors of the photoactive or electrode material. Furthermore, these devices require coatings with excellent barrier properties to achieve long term stability and compatibility with water. This results in an E-textile that is non-porous and non-permeable, inhibiting the breathability and moisture transfer characteristics of the fabric, which will significantly alter the feel to the wearer. This will also have some influence on the textile's heat transfer characteristics. This will not be the case for the textile proposed by Plentz et al. as shown in Figure 10, as this structure has large pores in it (however, the structure lacks the appearance of a normal textile) [124].

\section{Photovoltaic Wires, Fibers, and Yarns}

The potential of developing one-dimensional (1D) PV devices in the form of fibers, yarns, wires, or tapes for fabricating planar textile PV devices has been explored in the literature. Two main routes have been investigated for creating 1D PV devices. Initially, metal wires, carbon-based fibers or conductive polymer filaments were employed as the core of the device, with the other layers built on top to create the PV fibers. The other method presented in the literature utilized conventional polymeric textile fibers as the base material onto which the 1D PV devices were built. The latter approach is more desirable for retaining the textile features of the resultant planar structure, while the former allows for a simpler fabrication process and better device performance (in terms of PCE).

\subsection{D Photovoltaics Devices Using Non-Polymeric Fibers or Wires as a Core}

The use of metal wires or carbon based fibers as the core material to craft PV fibers, where the conductive core was coated with various photovoltaic material combinations to create organic, hybrid, or inorganic coaxial-fiber shaped solar cells, has been investigated in the literature.

Hybrid PV (predominantly DSSCs) technologies have dominated the research on PV fibers. The liquid or gel electrolytes used in most DSSCs are conformable and allow the PV fibers to deform while maintaining the integrity of the PV structure. However, DSSCs can suffer performance degradation caused by leakage of the electrolytes due to the deficiencies of the encapsulation.

\subsubsection{D DSSCs Using Non-Polymeric Fibers or Wires as a Core}

Early studies of 1D DSSCs from 2008 showed limited flexibility and mechanical robustness due to the capillary tube encasements being employed, and a poor adhesion between the Ti wire electrode and 
$\mathrm{TiO}_{2}$ nano coating [125]. Several reports have seen the metal wire counter-electrodes being replaced by transparent conductive metal oxide (e.g., ITO) capillary tubes; these tubes also served the purpose of encapsulating the device, however, they make the device stiff and rigid which is undesirable for a textile application. In 2011, Lv et al. reported a DSSC wire with a twisted working electrode/counter-electrode configuration encapsulated by an electrolyte filled capillary tube, which generated a PCE of 5.41\% [126]. This work used a rigid glass capillary tube; however, it is claimed that a flexible device could be created if the tube was replaced by a flexible polymer. Yang et al. managed to realize a PCE of $8.45 \%$ in 2013 with a $\mathrm{Ti} / \mathrm{TiO}_{2} / \mathrm{Pt}$ working electrode by replacing the Pt counter electrode with a Pt nanoparticle modified graphene oxide (GO) fiber [127]. High flexibility, good mechanichical strength, and good stability were claimed. A multi-working electrode structure with six $\mathrm{Ti} / \mathrm{TiO}_{2}$ working electrodes assembled around a Pt counter electrode was proposed by Liang et al. in 2015. The assembly was inserted into a flexible plastic capillary tube filled with a liquid electrolyte. This multi-working electrode structure achieved a PCE of $9.1 \%$ and was highly flexible [128]. Bend testing to different bending angles showed a good performance when the device was bent, maintaining a PCE of $8.5 \%$ with a $180^{\circ}$ bending angle.

DSSC PV fibers made with carbon-nanotube (CNT) working electrodes and counter electrodes have also been presented in the literature [129-131], which resulted in metal free PV fiber devices, improving the flexibility and ability for the fibers to be woven. This includes a DSSC by Chen et al. from 2012 which used two CNT fibers and a liquid electrolyte, creating a cell with a PCE of 2.94\%. The resultant fiber was reported to be both flexible and stable. The cell was also shown woven into a textile structure using other CNT fibers [129]. In 2012, Chen et al. also presented a DSSC that could achieve a PCE of 4.6\% [132]. Velten et al. developed a DSSC in 2013, also using CNT fiber electrodes and a liquid electrolyte, and achieved cells with PCEs as high as 3.4\% [130]. It was claimed that these fibers were weavable; however, this was not shown in the work. Zhang et al. proposed a modified CNT based DSSC fiber which used a liquid electrolyte in 2012, which could yield a PCE as high as $4.85 \%$, see Figure 11 [133]. The cell was flexible, showing little variation in performance when bent upto $180^{\circ}$. The cell was also tested after 500 bending cycles of $180^{\circ}$ showing some reduction in performance. Stability to air was shown over $20 \mathrm{~min}$ with a drop in effeiency from $3.43 \%$ to $3.16 \%$ reported. The authors note that an appropriate encapsulation is needed to ensure stability on a longer timescale.

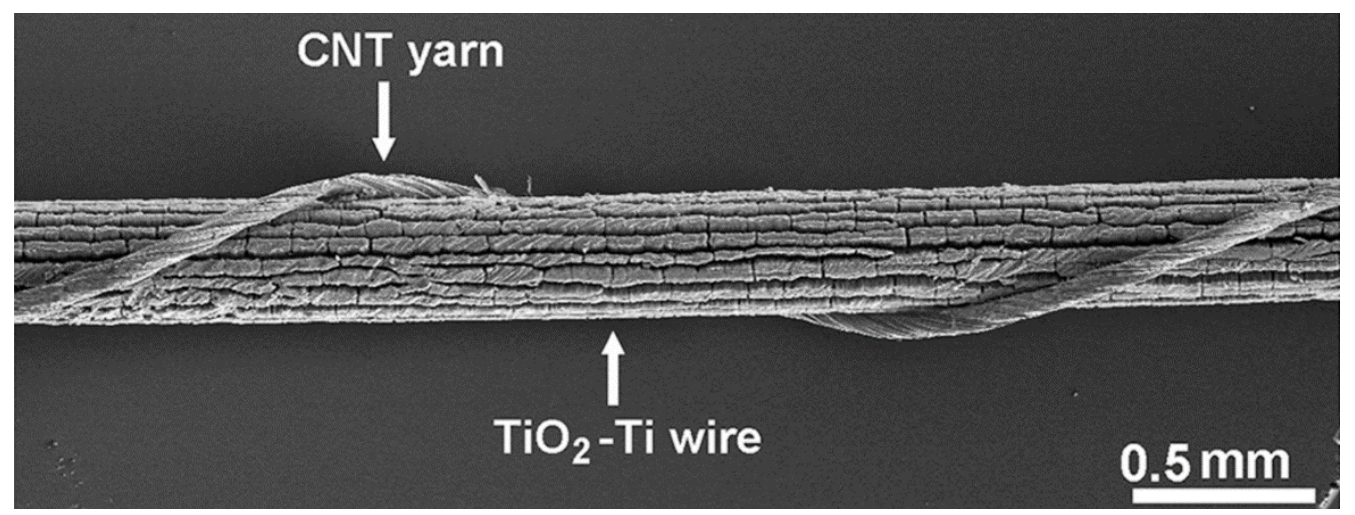

Figure 11. SEM image of a $\mathrm{TiO}_{2}$-Ti wire primary electrode diameter twisted around a carbon nanotube (CNT) yarn counter electrode. Reprinted (adapted) with permission from [133]. Copyright 2012 American Chemical Society.

Yan et al. presented a solid electrolyte-based twisted DSSC in 2014 which generated a PCE of $6.24 \%$ [131]. With a mirror placed behind the cell, a PCE of $\sim 7.39 \%$ was reported. The cell was flexible and showed little change in performance when bent up to $180^{\circ}$. The cell was also shown to have a stable perfromance when tested over a range of operating temperatures $\left(-10-48^{\circ} \mathrm{C}\right)$. The stability of this type of cell to multiple irradiation cycles (100), and exposed to atmosphereic conditions for up to 
$50 \mathrm{~h}$, was shown by the group in an earlier work in 2013 [134]. This particular cell had a PCE of $2.57 \%$ and also showed a stable performance over a range of temperatures $\left(0-45^{\circ} \mathrm{C}\right)$ and bending angles $\left(30-330^{\circ}\right)$.

In 2018, Fu et al. reported DSSC type PV fibers with a PCE of 10\%, the highest to date. The PV fibers were created using a core-sheath twisted CNT fiber counter electrode modified with Pt [135]. The DSSC fibers showed $>80 \%$ of its original efficiency after 2000 bending cycles with a $90^{\circ}$ bend. The long-term stability of the device was not reported. The researchers hand stitched the PV fibers onto a T-shirt and demonstrate their power generation capability by connecting the PV fibers to a commercial pedometer. This is a rare example of a developed solar E-textile being demonstrated to sucessfully power a sensing system.

\subsubsection{D Perovskite Solar Cells Using Non-Polymeric Fibers or Wires as a Core}

Perovskite-based 1D PV fibers have also been developed. These solar cells used a similar working electrode and counter electrode configuration to the DSSCs while the dye-electrolyte combination of a DSSC was replaced by a perovskite active material, enabling an all solid-state PV fiber.

One of the first perovskite PV fibers intended for use in fabrics was reported by Qiu et al. in 2014 [136], with this construction managing to generate a PCE of 3.3\%. This flexible device was shown to maintian $95 \%$ of its original efficency after 50 bending cycles. The device was also shown woven into a textile. He et al. followed a similar approach in 2015, with their highly-deformable PV fiber generating a PCE of $2.61 \%$ [137]. The PV fiber showed a $7 \%$ change in performance after 200 bending cycles where a $30^{\circ}$ bending angle was used. Hu et al. reported a perovskite PV yarn in 2016 which had a PCE of 5.3\% [138].

In 2015, Li et al. presented a double twisted perovskite yarn, which was developed by coating one $\mathrm{CNT}$ fiber bundle with $\mathrm{TiO}_{2} /$ sensitizer/hole transport layers and twisting it with another CNT fiber bundle [139]. This PV fiber realized a maximum PCE of 3.03\% and was stable after $96 \mathrm{~h}$ in ambient condition (if sealled with a polymer layer), and 1000 bending cycles. The angle by which the fiber was bent during each cycle was not presented in the work.

\subsubsection{D Coaxial Devices Using Non-Polymeric Fibers or Wires as a Core}

Coaxial fiber PV devices have also been created using OPVs (as shown in Figure 11) [140-142] inorganic PVs [143] or thin-film PVs [144]; however, these have not made significant advancements in performance and have not been frequently explored recently. This may be due to their unsatisfactory flexibility, mechanical robustness, the complexity of the production process. An early example includes work by Lee et al. in 2009, where they developed an OPV that could achieve a PCE of 3.27\% [141]. Later, Chuangchote et al. proposed fiber-based polymer photovoltaic cell designs in 2011 (see Figure 12), and explored various cell designs in a flat configuration; however, the greatest PCE reported was $0.11 \%[140]$.

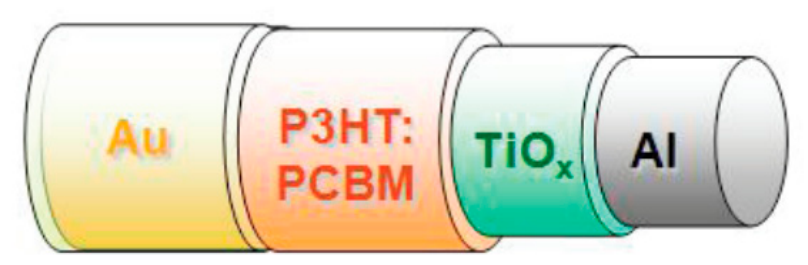

Figure 12. Schematic of a simple metal core based organic PV fiber. Reprinted from [140] with permission from Elsevier. This simple design has conducting inner and outer electrodes ( $\mathrm{Au}$ and $\mathrm{Al}$ ) and active layers (TiOx and P3HT:PCBM) forming the solar cell. This schematic provides a good example of a coaxial type solar cell, where the cell is built from multiple layers covering a core material.

Liu et al. created polymer based cells in 2012 [142] with PCEs as high as $2.3 \%$. Bendability was demonstrated, with the device showing little change when bent up to $90^{\circ}$. The long-term stability was 
explored, seeing a drop in efficiency to $1.77 \%$ after five days and then stabilizing at 1.6-1.7\% PCE up to day 14 (stored in inert gas). The paper also detailed a cell design where a CNT yarn was used as a counter electrode instead of a CNT film, showing a PCE of $2.11 \%$. This device showed little change in performance when bent up to $180^{\circ}$. A diagram illustrating the designs used is shown in Figure 13.

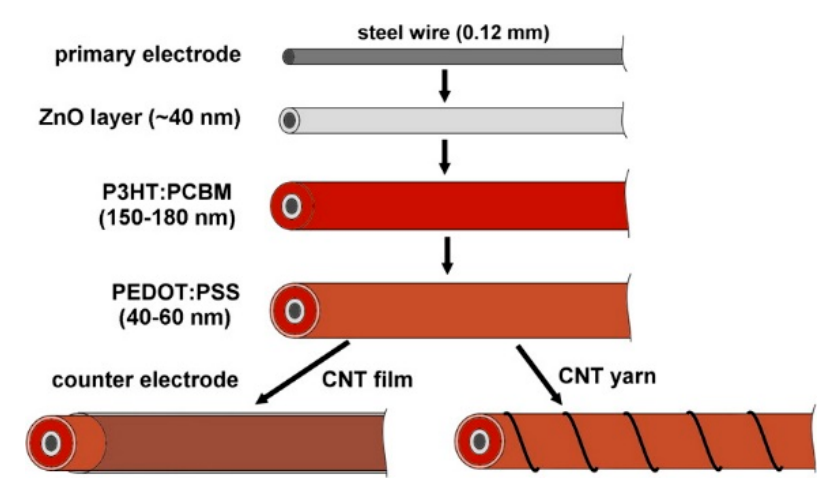

Figure 13. Diagram illustrating the fabrication process and structure of the fiber-shaped solar cells developed by Liu et al. Reprinted with permission from [142]. Copyright 2012 American Chemical Society.

In 2012, Zhang et al. proposed a cell design based on CdSe grown on a Ti wire [143]. The cells showed a PCE of 1-2\%. It was reported that the device remained stable when rotated or bent. A CuInSe 2 -based cell from 2012 could achieve a PCE of $2.31 \%$ [144], and was highly flexible showing only a small reduction in PCE when bent up to $360^{\circ}$. The device was also shown to be stable over a period of $600 \mathrm{~h}$.

\subsection{D Photovoltatic Devices Conducted Using Polymeric Fibers as a Core}

With the aim of creating a 1D PV device with improved mechanical robustness and conformability, studies have investigated PV fibers using a polymer core. In 2008 O'Connor and co-workers used a polyimide-coated silica fiber as the core of an OPV fiber, which had a PCE of $0.5 \%$ [145]. A DSSC fiber was realized by Toivola et al. in 2009, where both polymethyl methacrylate and glass optical fibers were explored for use as a core material. These PV fibers did not generate a notable amount of power (PCE $<0.1 \%$ for both the polymethyl methacrylate and glass optical fiber designs) [146]. Bedeloglu et al. fabricated a polymer PV fiber in 2010 starting with a polypropylene fiber core, this only generated a PCE of $0.021 \%$ [147].

A stretchable DSSC was presented by Yang et al. in 2014, where a CNT fiber tape was helically wrapped around a rubber fiber to be used as the elastic counter electrode [148]. A helical Ti/ $/ \mathrm{TiO}_{2}$ working electrode adsorbed with the dye-sensitizer was wrapped around the elastic counter electrode. This construction was highly conformable and was able to generate a PCE of $7.13 \%$ which was maintained during stretching. There was an insignificant change in PCE after 20 stretching cycles of $30 \%$.

\subsection{Discussion on Photovoltaic Wires, Fibers, and Yarns}

The key information regarding photovoltatic wires, fibers, and yarns is summarised in Table 2. 
Table 2. Summary of key information regarding the reported properites of various photovoltatic wires, fibers, and yarns. Please note that PCE (\%) are the values given and do not account for any differences in how the PCE may have been calculated between works.

\begin{tabular}{|c|c|c|c|c|c|c|c|}
\hline & $\begin{array}{l}\text { Type of } \\
\text { SC }\end{array}$ & $\begin{array}{l}\text { PCE } \\
(\%)\end{array}$ & $\begin{array}{c}\text { Mechanical } \\
\text { Deformability }\end{array}$ & Mechanical Durability & Washability & Stability & Other \\
\hline Ramier et al. [125] & DSSC & Nominal & & $\begin{array}{l}\text { Strain and bending } \\
\text { tested, however poor } \\
\text { mechanical } \\
\text { robustness reported. }\end{array}$ & & & \\
\hline Lv et al. [126] & DSSC & 5.41 & Rigid & & & & \\
\hline Yang et al. [127] & DSSC & 8.45 & $\begin{array}{l}\text { Flexible, high } \\
\text { mechanical strength }\end{array}$ & & & $\begin{array}{l}\text { Claimed to have } \\
\text { good stability }\end{array}$ & \\
\hline Liang et al. [128] & DSSC & 9.1 & Flexible & $\begin{array}{c}\text { Bend testing conducted } \\
\text { with different } \\
\text { bending angles }\end{array}$ & & & \\
\hline Chen et al. [129] & DSSC & 2.94 & Flexible & & & $\begin{array}{l}\text { Claimed to have } \\
\text { good stability }\end{array}$ & $\begin{array}{c}\text { Shown woven into } \\
\text { a textile }\end{array}$ \\
\hline Chen et al. [132] & DSSC & 4.6 & Flexible & & & & \\
\hline Velten et al. [130] & DSSC & 3.4 & Likely flexible & & & & \\
\hline Yan et al. [131] & DSSC & 6.24 & Flexible & & & $\begin{array}{l}\text { Stability shown in } \\
\text { earlier work }\end{array}$ & $\begin{array}{l}\text { Temperature } \\
\text { stability shown }\end{array}$ \\
\hline Zhang et al. [133] & DSSC & 4.85 & Flexible & 500 bending cycles & & Limited lifetime & \\
\hline Uddin et al. [134] & DSSC & 2.57 & Flexible & & & Stable over $50 \mathrm{~h}$ & $\begin{array}{l}\text { Temperature } \\
\text { stability shown }\end{array}$ \\
\hline Fu et al. [135] & DSSC & 10 & Flexible & 2000 bending cycles & & & $\begin{array}{c}\text { Shown powering } \\
\text { a pedometer }\end{array}$ \\
\hline Qiu et al. [136] & Perovskite & 3.3 & Flexible & 50 bending cycles & & & $\begin{array}{c}\text { Shown woven into } \\
\text { a textile }\end{array}$ \\
\hline He et al. [137] & Perovskite & 2.61 & $\begin{array}{l}\text { Flexible, twistable, } \\
\text { 3D deformable }\end{array}$ & $\begin{array}{l}200 \text { bending cycles, } \\
100 \text { twisting cycles }\end{array}$ & & & $\begin{array}{c}\text { Shown woven into } \\
\text { a textile }\end{array}$ \\
\hline Hu et al. [138] & Perovskite & 5.3 & & & & & \\
\hline Li et al. [139] & Perovskite & 3.03 & Flexible & 1000 bending cycles & & $\begin{array}{c}89 \% \text { of initial } \\
\text { performance after } \\
96 \mathrm{~h}\end{array}$ & \\
\hline
\end{tabular}


Table 2. Cont.

\begin{tabular}{|c|c|c|c|c|c|c|c|}
\hline & $\begin{array}{l}\text { Type of } \\
\text { SC }\end{array}$ & $\begin{array}{l}\text { PCE } \\
(\%)\end{array}$ & $\begin{array}{l}\text { Mechanical } \\
\text { Deformability }\end{array}$ & Mechanical Durability & Washability & Stability & Other \\
\hline Chuangchote et al. [140] & OPV & 0.11 & & & & & \\
\hline Lee et al. [141] & OPV & 3.27 & Flexible & & & & \\
\hline Liu et al. [142] & OPV & 2.3 & Flexible & & & $\begin{array}{c}\text { PCE of } 1.7 \% \text { after } \\
14 \text { days }\end{array}$ & \\
\hline Zhang et al. [143] & $\begin{array}{l}\text { Flexible } \\
\text { inorganic }\end{array}$ & 2 & Flexible & & & & \\
\hline Zhang et al. [144] & $\begin{array}{l}\text { Flexible } \\
\text { inorganic }\end{array}$ & 2.31 & Flexible & & & $\begin{array}{l}\text { Stable when tested } \\
\text { for } 600 \mathrm{~h}\end{array}$ & \\
\hline O'Conner et al. [145] & OPV & 0.5 & & & & & \\
\hline Toivola et al. [146] & DSSC & $<0.1$ & & & & & \\
\hline Bedeloglu et al. [147] & OPV & 0.021 & Flexible & & & & \\
\hline Yang et al. [148] & DSSC & 7.13 & Flexible, stretchable & $\begin{array}{c}20 \text { stretch cycles at } \\
30 \% \text { stretch }\end{array}$ & & & \\
\hline
\end{tabular}


As with devices constructed with PV films or coatings, flexability is a commonly reported property. Many of these works also demonstrated the durability of the PV devices to multiple bend cycles. Further, the ability to weave some of these devices has been reported. Beyond bending, He et al. presented a twistable device that was also 3D deformable [137], and Yang et al. presented a stretchable device [148]. The long term stability of these devices has only been reported in a few cases. PCEs for these types of devices ranged from being negiligable to $10 \%$ for the DSSCs produced by Fu et al. [135].

The textile performance of fiber- and tape-based PV devices needs to be explored in planar form (i.e., fabric form) in order to truly establish their feasibility for wearable applications. Their mechanically robustness, aesthetics, and wash durability in fabric structures need to be fully examined. The long-term stability of the devices must also be understood. In principle, these PV fiber devices can be used to make fabrics that exhibit some desirable textile characteristics, such as air permeability and shear deformability; however, their appearance, surface texture, and flexibility may be significantly different from that of textile fabrics made of conventional textile yarns intended for wearable applications.

\section{Textiles Woven from Photovoltatic Fibers}

Flexible planar PV devices can be created by integrating fibers, yarns or tapes containing PV materials into a woven structure.

Fabrics woven with yarns or tapes made from PV materials benefit from the inherent flexibility and conformability rendered by the interlacing of yarns or narrow-tapes in the woven structure, where the individual elements of the weave are free to undergo relative deformations due to external stresses, even if the individual elements are not stretchable. A woven textile with yarns or tapes made from PV materials would also allow the structure to permeate air and moisture, which is critical for a wearable application.

Most of the woven fabrics in the literature created PV modules by combining separate working electrode and counter electrode fibers within the weave structure. Here the interlacing points within the woven structure provided the electrical interconnects to complete the fully functioning PV cell. Another approach is to use fully functional PV wires or yarns with both the electrodes (working electrode and counter electrode) incorporated within the same strand.

In most cases, these woven devices did not report power densities based on the total planar area over which the PV wires were distributed, but instead power densities based on the area covered by the PV elements (wires or narrow tapes). It is important to note that a realistic comparison of such woven devices can only be made with the power densities where the whole fabric area was considered.

\subsection{Using Interlacing Points to Complete the Photovoltatic Device}

An early example of a woven PV fabric was reported in 2012, where a Cadmium selenide (CdSe) coated Ti wire working electrode was interlaced with a set of CNT yarn counter-electrodes [149]. This device demonstrated how a photovoltaic planar structure can be fabricated by using interlacing points to create electrical contacts. The coated wires had a PCE of $1.24 \%$, which was lower than the same coated wire twisted with a CNT counter electrode (PCE of $2.9 \%$; included in Table 2). This was attributed to the comparatively low number of contact points, and to the contact pressure between the two electrodes in the woven structure.

In 2014, Pan et al. prepared woven mesh electrodes which were stacked together to create a DSSC fabric structure (see Figure 14 for an image of the device), where the stacked electrodes were sealed and injected with an electrolyte to realize a DSSC which exhibited a PCE of $3.10 \%$ using a liquid electrolyte, or $2.1 \%$ when using a solid electrolyte [150]. Bending of the device (when made using a liquid electrolyte) showed little effect on performance, and when tested over 100 bending cycles, a change of less than $10 \%$ of the initial PCE was observed. The device also worked when under shear deformation, a property seldom reported for E-textiles in the literature. The performance of the DSSC that used a solid electrolyte varied by less than $5 \%$ after 100 bending cycles. The device was also highly stable, showing a less than a $6 \%$ drop in the original PCE after being exposed to air for $300 \mathrm{~h}$. 
The PCE of the device showed less dependency on the incident angle of the light in comparison to the planar devices; this behavior is desirable for mobile applications, where the incident light angle is unpredictable. The reason for this uniformity in performance was due to the circular cross sections of the electrodes and the spacing between the adjacent electrodes in the same plane of the fabric; this spacing minimized the shading effect from nearby electrodes at higher incident angles.

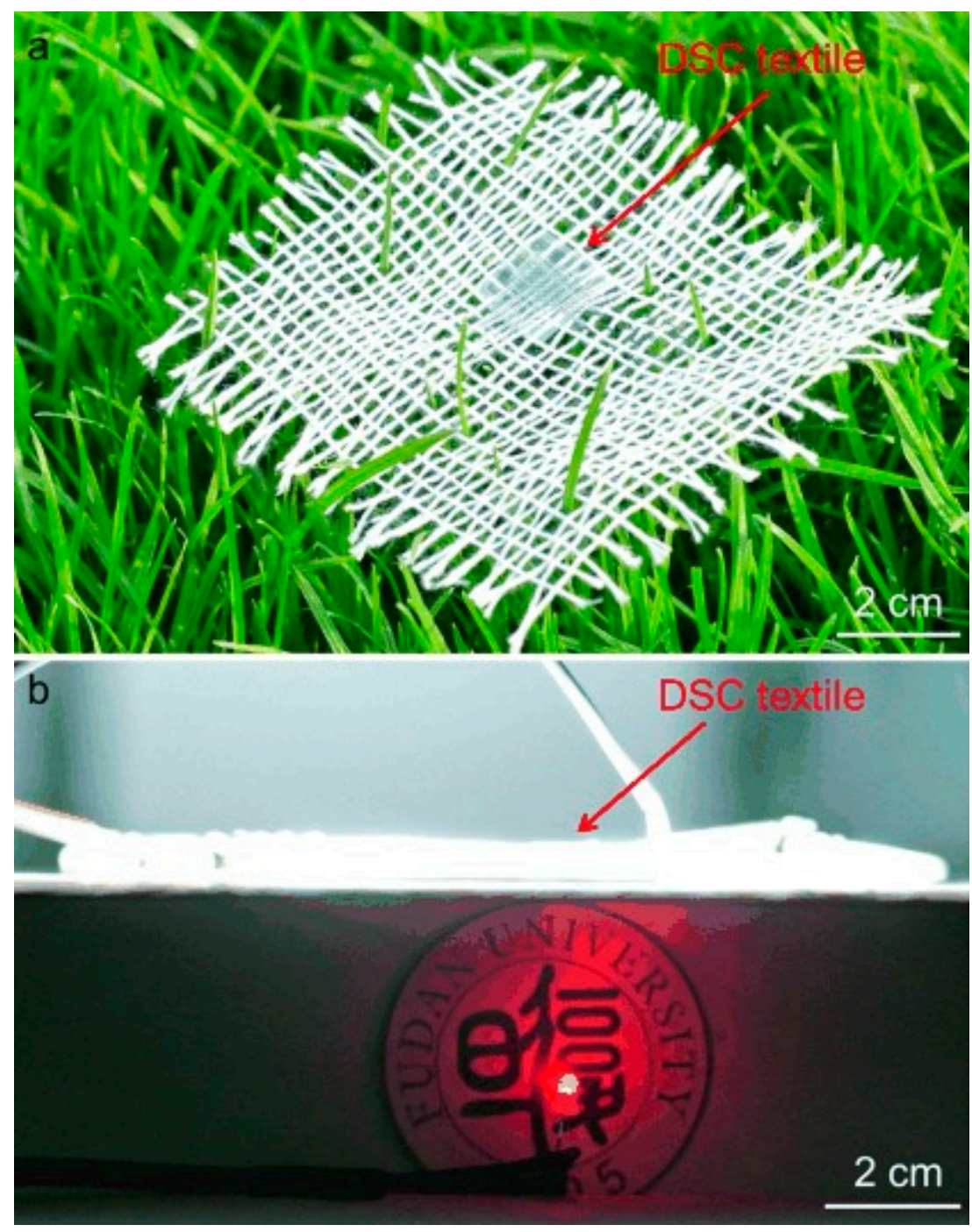

Figure 14. Photographs of the DSSC developed by Pan et al. (a) The DSSC. (b) The DSSC lighting up an LED. Reprinted from [150] with permission from Wiley.

In an effort to improve the textile appearance and feel of PV woven textiles, a few attempts to weave PV fiber devices together with conventional textile yarns have been reported in the literature [151-153]. In 2015, Zhang et al. demonstrated a PV woven fabric by interlacing all-solid-state co-axial DSSC working electrodes (weft yarns) with metal coated polymer counter electrode (warp yarns) [152]. The functioning solar cell was completed by using the warp-weft interlacing points for the electrical connections between the two electrodes. A single wire solar cell unit was reported to have a PCE of $1.3 \%$, which is lower than some core-sheath type DSSC fibers. Mechanical stress analysis of the PV elements within the woven structure was conducted and the effect of mechanical stress on the PV performance was studied. Furthermore, the effect of the counter electrode (warp) density and the woven pattern (plain, twill or satin) on the PV performance was analysed. The warp densities and the weave structure which realised the highest number of interlacing points (or the contact points between the warp and 
weft) yielded the best PCEs. Bending tests were conducted at different angles, and no significant change in performance was reported. Cyclic bend testing showed with no significant change in performance after 500 cycles. Fabrics woven using the aforementioned PV fibers and wool yarns were also presented and had a normal textile appearence, and while the energy harvesting capability of the wool blended fabric was not investigated, it was shown to power a digital calculator. The device was also shown to be reasonably stable after 60 days when stored in dry conditions. The same DSSC wire structure was utilized by the team to prepare an all-solid-state textile woven device to simultaneously harvest and store solar energy, which had a PCE of $\sim 1 \%$; however it was not clear whether this PCE calculation was based on the fabric area or the wire area [151]. The researchers reported that the device had a stable performance after two months of exposure to ambient conditions, and after 100 bending cycles of $120^{\circ}$. A similar woven textile that can harvest solar and mechanical energy simultaneously [154] has also been reported. The fabric generated a power density of $25 \mu \mathrm{W} / \mathrm{cm}^{2}$ when worn by a human walking in daylight (light intensity $=80 \mathrm{~mW} / \mathrm{cm}^{2}$ ).

Liu et al. reported a woven PV structure in 2018, created by weaving OPV working electrode wires as a weft with counter electrodes as a warp [153]. This work successfully demonstrated the weaving of fiber-shaped PV structures using an industry standard weaving loom, which was a key milestone for textile PV devices. This fabric also employed an interlacing technique to achieve electrical interconnections between the working electrodes and counter electrode wires. The resultant woven fabric exhibited a PCE of $1.62 \%$ (in wire form). The device was stable showing $10 \%$ degradation in performance after 15 days exposed to air. The fabric showed a less than $15 \%$ reduction in performance after bending up to $80^{\circ}$ and exhibited no deterioration of performance after $100020^{\circ}$ bending cycles and $1000180^{\circ}$ twisting cycles, indicating excellent stability under mechanical deformation. The fabric was very similar to a regular woven fabric in terms of appearance. The device is claimed to be breathable. The device was also demonstrated powering a digital watch. Ultimately the study demonstrated a PV device that possessed many desirable textile properties; however, the PCE was still low compared to coated or laminated textile PV devices. Increasing the density of the working electrodes would increase the PCE of the fabric; however, this would have significant implications for the conformability and softness of the fabric.

\subsection{Weaving Photovoltaic Ribbons or Tapes}

One approach to improve the PCE of woven solar E-textiles is to replace the PV wires with pre-fabricated PV ribbons (also referred to as tapes) [26,155-157]. These ribbons were either complete PV devices or constituted some of the active PV layers. PV ribbons have a larger active area and can cover a significantly larger proportion of the available planar surface compared to PV wires. However, PV ribbons can also significantly alter the conformability and appearance of the final fabric depending on the stiffness of a single ribbon and the number of ribbons per unit length within the fabric.

Yun et al. fabricated a woven PV device in 2015 by inserting DSSC-type PV ribbons using a conventional weaving machinery, with the device exhibiting a PCE of $2.63 \%$ [156]. These flexible ribbons maintained a performance of $85 \%$ of their initial PCE when bent with a $3 \mathrm{~cm}$ radius of curvature. In 2015, Krebs and Hösel employed pre-fabricated OPV tapes ( $2 \mathrm{~cm}$ wide) to weave a large area $\left(25 \times 25 \mathrm{~cm}^{2}\right)$ woven solar cell textile [155]. The solar tapes woven into the structure consisted of 16 serially connected organic solar cells with a PCE of $1 \%$.

A ribbon-shaped hybrid PV device that could harvest and store solar energy was reported by Li et al. in 2016 [26]. The ribbon was prepared by stacking a perovskite flexible PV film onto a thin film electrochemical supercapacitor, with the top electrode of the supercapacitor also acting as the counter electrode of the PV device. The perovskite PV film generated an impressive $10.41 \%$ PCE (under 1 Sun intensity). The cells were bendable, showing a reduction in initial PCE of $10 \%$ after 100 bending cycles of $120^{\circ}$. A $10 \%$ reduction from the initial PCE was also observed when the laminated cells were exposed to air for ten days. These ribbons could be inserted into a woven structure to demonstrate a 
wearable energy device; however, this did not resemble a textile material due to large widths $(>1 \mathrm{~cm})$ of the tapes used in the work.

A textile-based solar energy harvesting and storage system was created by Kuhlmann et al. in 2018. The device was created by weaving flexible CIGS thin-film PV cells (44 mm wide) with conventional textile yarns and attaching commercially available flexible batteries (solid-state lithium batteries having a thickness of $0.4 \mathrm{~mm}$ ) [157]. Krebs and Hösel have argued that woven PV tapes are one of the most technically feasible and commercially viable stratergies for incorporating PV functionality with textiles [155]; however, it is doubtful whether such devices are acceptable for use in future wearables intended for day-to-day use, mainly due their lack of normalcy.

\subsection{Discussion on Textiles Woven from PV Fibers, Ribbons or Tapes}

The key information regarding textiles woven using PV fibers, ribbons or tapes are summarised in Table 3.

Flexibility was shown for PV textiles woven using PV fibers, ribbons, and tapes. Many examples in the literature demonstrate the durability of the textiles to repeated bending cycles. Work by Liu et al. also showed twist and twist-durabilty, and Pan et al. showed that the textile had shear behaviour, a crticial factor for a normal textile feel. Given the inherent porous structure, this type of device would also be breathable and would exhibit some moisture transfer characteristics. However, in some cases, the need to fully encapsulate the device will hinder the permeability and flexibility of the final product. This will also alter the appearence.

The long term stabilty of some devices have been reported, with two DSSCs shown to be stable after about two months [151,152]. PCEs reported for these devices vary, with the highest PCE being reported by Li et al. for their Pervoskite device, with an impressive PCE of 10.41\% [139].

Further testing is still required to fully understand the viability of this type of PV device for wearable garments. For example, the electrical interconnections achieved by the interlacing points for some devices may not by reliable during the deformations undergone by the resultant garments, and these interconnections could deteriorate during washing and wearing. 
Table 3. Summary of key information regarding the reported properites of various textile woven using photovoltatic fibers, ribbons, or tapes. Please note that PCE (\%) are the values given and do not account for any differences in how the PCE may have been calculated between works.

\begin{tabular}{|c|c|c|c|c|c|c|}
\hline & Type of SC & PCE (\%) & $\begin{array}{c}\text { Mechanical } \\
\text { Deformability }\end{array}$ & $\begin{array}{l}\text { Mechanical } \\
\text { Durability }\end{array}$ & Washability & Other \\
\hline Zhang et al. [149] & Inorganic & 1.24 & Flexible & & & $\begin{array}{c}\text { Shown as a woven } \\
\text { device }\end{array}$ \\
\hline Pan et al. [150] & DSSC & 3.67 & $\begin{array}{l}\text { Flexible, shear } \\
\text { behavior }\end{array}$ & 100 bending cycles & & $\begin{array}{c}\text { Shown as a woven } \\
\text { device, shown } \\
\text { powering an LED }\end{array}$ \\
\hline Pan et al. [150] & $\begin{array}{l}\text { DSSC (solid } \\
\text { electrolyte } \\
\text { example) }\end{array}$ & 2.1 & Flexible & 100 bending cycles & $\begin{array}{l}\text { Stable when tested for } \\
\qquad 300 \mathrm{~h} \text { in air }\end{array}$ & $\begin{array}{c}\text { Shown as a woven } \\
\text { device }\end{array}$ \\
\hline Zhang et al. [152] & DSSC & 1.3 & Flexible & 500 bending cycles & Stable after 60 days & $\begin{array}{l}\text { Shown as a woven } \\
\text { device, normal textile } \\
\text { appearance, shown } \\
\text { powering a calculator }\end{array}$ \\
\hline Chai et al. [151] & DSSC & 1 & Flexible & 100 bending cycles & $\begin{array}{l}\text { Stable after two } \\
\text { months }\end{array}$ & $\begin{array}{c}\text { Shown as a woven } \\
\text { device }\end{array}$ \\
\hline Chen et al. [154] & DSSC & & Flexible & & & $\begin{array}{l}\text { Shown as a woven } \\
\text { device, foldable, } \\
\text { hybrid energy } \\
\text { harvesting device }\end{array}$ \\
\hline Liu et al. [153] & OPV & 1.62 & Flexible, twistable & $\begin{array}{l}1000 \text { bending } \\
\text { cycles, } \\
1000 \text { twisting } \\
\text { cycles }\end{array}$ & $\begin{array}{l}\text { Stable after } 15 \text { days } \\
(10 \% \text { reduction in } \\
\text { initial PCE })\end{array}$ & $\begin{array}{l}\text { Shown as a woven } \\
\text { device, normal textile } \\
\text { appearance }\end{array}$ \\
\hline Yun et al. [156] & DSSC & 2.63 & Flexible & & & $\begin{array}{c}\text { Shown as a woven } \\
\text { device }\end{array}$ \\
\hline Krebs and Hösel [155] & OPV & 1 & Flexible & & & $\begin{array}{c}\text { Shown as a woven } \\
\text { device }\end{array}$ \\
\hline Li et al. [26] & Perovskite & 10.41 & Flexible & 100 bending cycles & $\begin{array}{l}\text { Stable after } 10 \text { days } \\
(10 \% \text { reduction in } \\
\text { initial PCE) }\end{array}$ & $\begin{array}{c}\text { Shown as a woven } \\
\text { device }\end{array}$ \\
\hline Kuhlmann et al. [157] & CIGS & & Likely flexible & & & $\begin{array}{c}\text { Shown as a woven } \\
\text { device }\end{array}$ \\
\hline
\end{tabular}




\section{Non-Woven Photovoltaic Textiles}

Non-woven textile structures such as electrospun nano-fiber webs or fiber membranes have also been investigated as a substrate for textile PV devices [158-160].

In 2010, Sundarrajan et al. realised an electrospun polymeric PV web [158]. The active polymer layer of the PV web was sandwiched between transparent conductive electrode films. A notable PCE was not reported for the device.

A DSSC based on a PET membrane (as the medium for liquid electrolyte) was developed by Sun et al. in 2016 [159], which reported a PCE of $10.2 \%$. The stability of these cells was investigated and monitored over four weeks at atmospheric conditions and $60{ }^{\circ} \mathrm{C}$, with most varients of these cells maintaining $70-75 \%$ of their initial PCE after this time. The photoanode and counterelectrodes used in this device were monolithic and non-conformable, hence the device did not possess qualtities that were desirable for wearable applications.

A DSSC PV device with textile-based counter electrodes was investigated by Junger et al. in 2018 [160]. The PV device was conformable, however the PCE achieved was not noteworthy.

\section{Discussion about Solar Energy Harvesting Textiles}

This review has collated various literature sources where PV has been incorperated with textiles to provide energy harvesting capabilities. The review has highlighted the various means by which PV can be combined with textiles, and when reported, has highlighted the textile characteristics of these devices.

\subsection{Textile Properties of Photovoltaic Textiles}

While capable of generating significant amounts of power, attaching flexible solar panels onto garments will significantly affect the look and feel of the textile. While these asthetics may be desirable for some niche applications, such as for fashion prototypes, this is not favorable for most consumer applications. By including solar panels on the textile in a dispersed pattern some flexibility and drapeability can be maintained, which may be acceptable for heavy outwear; however this would likely be uncomfotable if applied to a garment that is intended to be worn close to the skin. Similarly, the presence of attached solar panels will negatively affect the heat and moisture transfer characteristics of the garment. From the available literature, the durablility of garments of this type is unclear.

Solar cell arrays can lack a normal textile appearance, and while being flexible, do not necessarily exhibit other textile properties such as shear deformability, which is key for drapability. Embedding arrays of solar cells within yarns was the only example in the literature of solar cell array-based fabric that maintained a normal textile appearance and textile properties (i.e., drape, washability) [101].

PV films or coatings can be applied onto textiles; however, in order to achieve long term stability and compatibility with water, the devices have to undergo an encapsulation step using a thin film or a flexible coating (which are sometimes elastic) with excellent barrier properties. Regardless of the approach, the use of an encapsulation step results in solar E-textiles that are non-permeable and that have a non-porous structure. Despite being inherently flexible, when applied onto large area textiles (which are inherently porous due to the openness of woven or knitted structures), these PV materials inhibit the air and moisture permeability of the base textile, which is critical for the comfort of the wearer, especially during warm and humid conditions. These systems also affect the appearance and feel of the textile. Limited information is presented on the durability of the textiles for wearable applications, however Jinno et al. demonstrated the washability of their OPV film-based device [104]. Jeong et al., in 2019, also demonstrated the washability and water compatibility for their OPV device, as well as resilience to bend testing [115]. While these two devices showed great promise in achieving wash durable PVs, the washability and water compatibility tests employed in these studies were mild, and far from the vigorous hydro-mechanical, thermal and chemical processes undergone by regular clothing in a domestic machine washing. 
There has been a wide range of work investigating fiber/wire/tape-shaped PV devices intended to be transformed into planar form (e.g., a woven textile); however, many have only been demonstrated in fiber/wire form. Tests of this type of PV device have largely been limited to flexibility and durability to repeated bending cycles.

Similarly, fabrics woven with PV-coated wires or flexible PV tapes are often only tested for their flexibility. Given their woven nature, these PV devices will have a porous structure and should be breathable and exhibit moisture transfer characteristics. The structure may also give these devices a more normal textile behavior (i.e., shear). Some PV devices of this type will not have a normal textile appearance; the OPV-based fabric created by Liu et al. is one example of a solar E-textile that maintained the aesthetics of a regular fabric [153].

From the existing literature, it is evident that most of the work on solar E-textiles to date has not focused on the textile aspects of the E-textile. In most of the literature, flexibility is considered the prime requirement for wearability; however, in reality it is often a combination of many facets such as softness, shear behavior (this is key to three-dimensional conformability), appearance, air/moisture permeability, heat-transfer characteristics and wash durability. There exists a gap in knowledge on how these features can be achieved, while maintaining satisfactory power conversion efficiencies. The physical durability of the textile is also highly important for a wearable application, however beyond flexibility/bending, few examples of durability testing have been presented. Table 4 summarizes examples of solar E-textile where considerations beyond flexibility have been reported.

It is clear that further extensive testing of solar E-textiles is necessary, both to characterize properties and to ascertain their durability. The lack of testing for textile properties to date is likely in part due to the limited scale of production of these PV devices. Certain types of textile testing may prove critical for some solar E-textile designs, for example, abrasion testing may wear away the thin protective encapsulation necessary for many of the proposed designs, significantly limiting lifetime. Damaging the protective encapsulant may also lead to the wearer being exposed to the constituent materials of the solar cell. This may be problematic for lead-containing perovskite solar cells, which may pose a safety risk.

The stability of many solar E-textiles also needs to be improved. If used in a commercial product, the solar elements will be expected to remain functional for many years. This may influence the technologies and materials adopted moving forwards. While exhibiting good PCEs, even state-of-the-art perovskite solar cells (not designed not textile applications) only retain their initial performance for several months [161]. This is in part due to perovskite's instability to moisture and oxygen. Perovskite also has poor thermal stability, and degrades when exposed to light.

Table 5 summarizes details about the different methods used to create solar E-textiles. 
Table 4. Examples of solar E-textiles were textile properties other than flexibility and durability to repeated bending have been reported. Please note that PCE (\%) are the values given and do not account for any differences in how the PCE may have been calculated between works.

\begin{tabular}{|c|c|c|c|c|c|c|}
\hline & Type of SC & PCE (\%) & $\begin{array}{c}\text { Mechanical } \\
\text { Deformability }\end{array}$ & $\begin{array}{l}\text { Mechanical } \\
\text { Durability }\end{array}$ & Washability & Other \\
\hline Satharasinghe et al. [101] & c-Si array & 2.15 & $\begin{array}{l}\text { Shear behavior, } \\
\text { drapeable }\end{array}$ & $\begin{array}{l}\text { Abrasion testing to } \\
6000 \text { abrasion cycles }\end{array}$ & $\begin{array}{l}\text { Retained } \sim 90 \% \text { of } \\
\text { their original power } \\
\text { output after } 15 \\
\text { machine wash cycles }\end{array}$ & $\begin{array}{c}\text { Woven device, shown } \\
\text { powering various } \\
\text { devices }\end{array}$ \\
\hline Lipomi et al. [111] & OPV film & 2 & Stretchable & & & \\
\hline Kaltenbrunner et al. [112] & OPV film & 4 & $\begin{array}{c}\text { Stretchable, 3D } \\
\text { deformation (drape) }\end{array}$ & $\begin{array}{l}\text { Cyclic compression } \\
\text { tested to } 22 \text { cycles. }\end{array}$ & & \\
\hline Jinno et al. [104] & OPV film & 7.9 & Stretchable & $\begin{array}{l}\text { Cyclic compression } \\
\text { testing to } 20 \text { cycles. }\end{array}$ & $\begin{array}{l}\text { Compatible with } \\
\text { water, washable } \\
\text { under mild } \\
\text { conditions. }\end{array}$ & \\
\hline Lam et al. [108] & $\begin{array}{l}\text { Perovskite } \\
\text { laminate }\end{array}$ & 15 & & & $\begin{array}{l}\text { Compatible with } \\
\text { water }\end{array}$ & \\
\hline He et al. [137] & Perovskite fiber & 2.61 & $\begin{array}{l}\text { Twistable, 3D } \\
\text { deformable }\end{array}$ & 100 twisting cycles & & $\begin{array}{c}\text { Shown woven into a } \\
\text { textile }\end{array}$ \\
\hline Yang et al. [148] & DSSC fiber & 7.13 & Stretchable & $\begin{array}{l}20 \text { stretch cycles at } \\
30 \% \text { stretch }\end{array}$ & & \\
\hline Pan et al. [150] & $\begin{array}{l}\text { DSSC woven } \\
\text { textile }\end{array}$ & 3.67 & Shear behavior & & & $\begin{array}{c}\text { Shown as a woven } \\
\text { device, shown } \\
\text { powering an LED }\end{array}$ \\
\hline Liu et al. [153] & $\begin{array}{l}\text { OPV woven } \\
\text { textile }\end{array}$ & 1.62 & Twistable & 1000 twisting cycles & & $\begin{array}{c}\text { Shown as a woven } \\
\text { device, normal textile } \\
\text { appearance }\end{array}$ \\
\hline
\end{tabular}


Table 5. Summary of key details reported on solar E-textiles. Not all devices will have these properties or PCEs. Please note that PCE (\%) are the values given and do not account for any differences in how the PCE may have been calculated between works.

\begin{tabular}{|c|c|c|c|c|c|c|}
\hline & $\begin{array}{c}\text { Maximum } \\
\text { Reported PCE }\end{array}$ & $\begin{array}{c}\text { Mechanical } \\
\text { Deformability }\end{array}$ & $\begin{array}{l}\text { Mechanical } \\
\text { Durability }\end{array}$ & Washability & $\begin{array}{c}\text { Maximum Stability } \\
\text { Reported }\end{array}$ & Other \\
\hline $\begin{array}{l}\text { Integrating flexible } \\
\text { solar panels with } \\
\text { textiles }\end{array}$ & $\begin{array}{l}\text { Dependent on } \\
\text { attached cell }\end{array}$ & Flexible & $\begin{array}{l}\text { Likely durable to } \\
\text { some wear and use }\end{array}$ & Not reported & $\begin{array}{c}\text { The a-Si type of cells } \\
\text { used are typically } \\
\text { stable }\end{array}$ & \\
\hline Solar cell arrays & 14.9 & $\begin{array}{c}\text { Flexible, shear } \\
\text { behavior, drapeable }\end{array}$ & $\begin{array}{l}\text { Abrasion testing to } \\
6000 \text { abrasion cycles }\end{array}$ & $\begin{array}{l}\text { Water compatible, can } \\
\text { be machine washed }\end{array}$ & $\begin{array}{l}\text { c-Si type cells are } \\
\text { typically stable }\end{array}$ & Breathable \\
\hline $\begin{array}{l}\text { PV films and coating } \\
\text { applied to textiles }\end{array}$ & 7.9 & Flexible, stretchable & $\begin{array}{l}\text { Cyclic bend testing, } \\
\text { cyclic compression } \\
\text { testing }\end{array}$ & $\begin{array}{l}\text { Water compatibility } \\
\text { reported, can be } \\
\text { washed under mild } \\
\text { conditions }\end{array}$ & $\begin{array}{l}\text { No degradation after } \\
30 \text { days reported }\end{array}$ & \\
\hline $\begin{array}{l}\text { Photovoltaic wires, } \\
\text { fibers, and yarns }\end{array}$ & 10 & $\begin{array}{l}\text { Flexible, twistable, } \\
\text { stretchable, 3D } \\
\text { deformable }\end{array}$ & $\begin{array}{l}\text { Cyclic bend testing, } \\
\text { cyclic stretching, } \\
\text { cyclic twisting }\end{array}$ & & $\begin{array}{l}\text { Stable after } 25 \text { days } \\
\text { reported }\end{array}$ & \\
\hline $\begin{array}{l}\text { Textiles woven from } \\
\text { photovoltatic fibers }\end{array}$ & 10.41 & $\begin{array}{l}\text { Flexible, twistable, } \\
\text { shear behavior }\end{array}$ & $\begin{array}{l}\text { Cyclic bending, cyclic } \\
\text { twisting }\end{array}$ & & Stable after 2 months & Breathable \\
\hline $\begin{array}{c}\text { Non-woven } \\
\text { photovoltaic textiles }\end{array}$ & 10.2 & & & & & \\
\hline
\end{tabular}




\subsection{Suitability for Powering E-Textile Sensing Systems}

The energy harvesting capability of a solar E-textile is the other key consideration of its suitability for powering an E-textile device. Different E-textile devices possess different energy needs depending on their function and use case; however, the power requirements for wearable devices typically range between tens and hundreds of milliwatts [162], with most mobile devices, such as mobile phones, smart watches and fitness trackers, requiring $50 \mathrm{~mW}$ to $1000 \mathrm{~mW}$ during normal use [163].

While some solar E-textiles shown in the literature exhibit a poor PCE, many have a PCE of over $1 \%$, and PCEs exceeding $10 \%$ have also been reported [159]. Textiles and garments are large structures providing a significant area onto which PV technology can be integrated. Therefore, despite lower PCEs than conventional solar cells, the inefficiency in power conversion of the textile PV devices can be partially mitigated by harvesting energy over a large area. One Sun intensity is $100 \mathrm{~mW} / \mathrm{cm}^{2}$; therefore, a solar E-textile with a conservative PCE of $1 \%$ covering an area of $1000 \mathrm{~cm}^{2}$, would be able to power a device that requires $1 \mathrm{~W}$. An active area of this size could easily be fit onto the back of a conventional T-shirt. This scenario, however, assumes ideal conditions where the light intensity continuously reaching the solar E-textile is $100 \mathrm{~mW} / \mathrm{cm}^{2}$, which would not be true in most cases given shading, cloud cover, or change in the angle of incident light. Due to a potentially inconsistent intensity of light reaching the solar E-textiles, most systems would likely employ energy storage as part of their power management electronics.

Fully assessing the suitability of different solar E-textiles for powering E-textile devices is difficult given the widely varying power requirements, intended application (as this will influence the intensity of light reaching the device), and garment design parameters (potentially limiting the size of the active area). Despite this, solar E-textiles remain the best candidate for harvesting energy levels sufficient to power wearable devices.

\subsection{Future Perspectives for Solar Energy Harvesting Textiles for Wearable Applications}

This review has identified the key methods explored in the literature to intergrate solar energy harvesting functionality into textiles. Beyond attaching solar cells to outerwear, most integration technologies are far away from being ready as commerical devices. Given the level of maturity of these technolgies compared to other devices in the E-textiles field, it is likely that the trend of using batteries to power E-textiles will continue while the exciting innovations described in this review evolve further.

The future advancement and, ultimately, the adoption of solar E-textiles will require the textile characteristics to be fully quantified and the durability of the devices for use as textile garments to be understood. This will be challenging given the lack of standards currently available for the testing of E-textiles (currently only BS EN 16812:2016 exists). Many devices, in their present form, may not possess the desired properties or robustness, and therefore further development will be needed; however, this is difficult to conclusively comment on without testing data. The stability of many solar E-textiles will also need to be improved to allow for the long term use demanded of a product. The processes to manufacture these textile solar cells at a large scale will also be nessisary.

Finally, power management will need to be addressed. The output from a solar E-textile will not be continuous due to the movement of the wearer, and the position of the Sun. A further hurdle to the adoption of solar E-textiles will be the creation of power management electronics that can also be discretely integrated within a textile.

Author Contributions: Writing—original draft preparation, A.S. and T.H.-R.; writing—review and editing, A.S., T.H.-R., and T.D.; supervision, T.H.-R. and T.D. All authors have read and agreed to the published version of the manuscript.

Funding: This research received no external funding.

Conflicts of Interest: The authors declare no conflict of interest. 


\section{References}

1. Weng, W.; Chen, P.; He, S.; Sun, X.; Peng, H. Smart electronic textiles. Angew. Chem. Int. Ed. 2016, 55, 6140-6169. [CrossRef] [PubMed]

2. Stoppa, M.; Chiolerio, A. Wearable electronics and smart textiles: A critical review. Sensors 2014, 14, 11957-11992. [CrossRef] [PubMed]

3. Zeng, W.; Shu, L.; Li, Q.; Chen, S.; Wang, F.; Tao, X. Fiber-based wearable electronics: A review of materials, fabrication, devices, and applications. Adv. Mater. 2014, 26, 5310-5336. [CrossRef] [PubMed]

4. Hughes-Riley, T.; Dias, T.; Cork, C. A Historical Review of the Development of Electronic Textiles. Fibers 2018, 6, 34. [CrossRef]

5. Wang, L.; Fu, X.; He, J.; Shi, X.; Chen, T.; Chen, P.; Wang, B.; Peng, H. Application challenges in fiber and textile electronics. Adv. Mater. 2020, 32, 1901971. [CrossRef]

6. Magno, M.; Boyle, D. Wearable energy harvesting: From body to battery. In Proceedings of the 201712 th International Conference on Design \& Technology of Integrated Systems In Nanoscale Era (DTIS), Palma de Mallorca, Spain, 4 April 2017; pp. 1-6.

7. Adapa, A.; Nah, F.F.; Hall, R.H.; Siau, K.; Smith, S.N. Factors influencing the adoption of smart wearable devices. Int. J. Hum. Comput. Interact. 2018, 34, 399-409. [CrossRef]

8. Zhai, S.; Karahan, H.E.; Wei, L.; Qian, Q.; Harris, A.T.; Minett, A.I.; Ramakrishna, S.; Ng, A.K.; Chen, Y. Textile energy storage: Structural design concepts, material selection and future perspectives. Energy Storage Mater. 2016, 3, 123-139. [CrossRef]

9. Jost, K.; Dion, G.; Gogotsi, Y. Garment devices: Integrating energy storage into textiles. In Fundamentals of Wearable Computers and Augmented Reality; CRC Press: Boca Raton, FL, USA, 2015; pp. 656-677.

10. Torah, R.; Lawrie-Ashton, J.; Li, Y.; Arumugam, S.; Sodano, H.A.; Beeby, S. Energy-harvesting materials for smart fabrics and textiles. MRS Bull. 2018, 43, 214-219. [CrossRef]

11. Sun, H.; Zhang, Y.; Zhang, J.; Sun, X.; Peng, H. Energy harvesting and storage in 1D devices. Nat. Rev. Mater. 2017, 2, 1-12. [CrossRef]

12. Conibeer, G.; Willoughby, A. Solar Cell Materials; John Wiley \& Sons, Ltd.: Chichester, UK, 2014.

13. Schubert, M.B.; Werner, J.H. Flexible solar cells for clothing. Mater. Today 2006, 9, 42-50. [CrossRef]

14. Mather, R.R.; Wilson, J.I. Fabrication of photovoltaic textiles. Coatings 2017, 7, 63. [CrossRef]

15. Singh, M.K. Flexible photovoltaic textiles for smart applications. Sol. Cells New Asp. Solut. 2011, 43-68. [CrossRef]

16. Hatamvand, M.; Kamrani, E.; Lira-Cantú, M.; Madsen, M.; Patil, B.R.; Vivo, P.; Mehmood, M.S.; Numan, A.; Ahmed, I.; Zhan, Y. Recent Advances in Fiber-Shaped and Planar-Shaped Textile Solar Cells. Nano Energy 2020, 104609. [CrossRef]

17. Ehrmann, A.; Blachowicz, T. Recent coating materials for textile-based solar cells. Aims Mater. Sci. 2019, 6, 234-251. [CrossRef]

18. Powering Wearables: Battery Types, Current Challenges, and Energy Harvesting. Available online: https://www.powerelectronicsnews.com/powering-wearables-battery-types-current-challengesand-energy-harvesting/ (accessed on 27 March 2020).

19. Jost, K.; Dion, G.; Gogotsi, Y. Textile energy storage in perspective. J. Mater. Chem. A 2014, 2, $10776-10787$. [CrossRef]

20. Kaushik, V.; Lee, J.; Hong, J.; Lee, S.; Lee, S.; Seo, J.; Mahata, C.; Lee, T. Textile-based electronic components for energy applications: Principles, problems, and perspective. Nanomaterials 2015, 5, 1493-1531. [CrossRef]

21. Hu, L.; Pasta, M.; La Mantia, F.; Cui, L.; Jeong, S.; Deshazer, H.D.; Choi, J.W.; Han, S.M.; Cui, Y. Stretchable, porous, and conductive energy textiles. Nano Lett. 2010, 10, 708-714. [CrossRef]

22. Jost, K.; Perez, C.R.; McDonough, J.K.; Presser, V.; Heon, M.; Dion, G.; Gogotsi, Y. Carbon coated textiles for flexible energy storage. Energy Environ. Sci. 2011, 4, 5060-5067. [CrossRef]

23. Bae, J.; Song, M.K.; Park, Y.J.; Kim, J.M.; Liu, M.; Wang, Z.L. Fiber supercapacitors made of nanowire-fiber hybrid structures for wearable/flexible energy storage. Angew. Chem. Int. Ed. 2011, 50, 1683-1687. [CrossRef]

24. Lau, D.; Song, N.; Hall, C.; Jiang, Y.; Lim, S.; Perez-Wurfl, I.; Ouyang, Z.; Lennon, A. Hybrid solar energy harvesting and storage devices: The promises and challenges. Mater. Today Energy 2019, 13, 22-44. [CrossRef]

25. Fu, Y.; Wu, H.; Ye, S.; Cai, X.; Yu, X.; Hou, S.; Kafafy, H.; Zou, D. Integrated power fiber for energy conversion and storage. Energy Environ. Sci. 2013, 6, 805-812. [CrossRef] 
26. Li, C.; Islam, M.M.; Moore, J.; Sleppy, J.; Morrison, C.; Konstantinov, K.; Dou, S.X.; Renduchintala, C.; Thomas, J. Wearable energy-smart ribbons for synchronous energy harvest and storage. Nat. Commun. 2016, 7, 13319. [CrossRef] [PubMed]

27. Beeby, S.P.; Cao, Z.; Almussallam, A. Kinetic, thermoelectric and solar energy harvesting technologies for smart textiles. In Multidisciplinary Know-How for Smart-Textiles Developers; Elsevier: Amsterdam, The Netherlands, 2013; pp. 306-328.

28. Stark, I. Integrating thermoelectric technology into clothing for generating usable energy to power wireless devices. In Proceedings of the Conference on Wireless Health; Association for Computing Machinery: New York, NY, USA, 2012; pp. 1-2.

29. Du, Y.; Cai, K.; Chen, S.; Wang, H.; Shen, S.Z.; Donelson, R.; Lin, T. Thermoelectric fabrics: Toward power generating clothing. Sci. Rep. 2015, 5, 6411. [CrossRef]

30. Cao, Z.; Tudor, M.J.; Torah, R.N.; Beeby, S.P. Screen printable flexible BiTe-SbTe-based composite thermoelectric materials on textiles for wearable applications. IEEE Trans. Electron. Devices 2016, 63, 4024-4030. [CrossRef]

31. Lee, J.A.; Aliev, A.E.; Bykova, J.S.; de Andrade, M.J.; Kim, D.; Sim, H.J.; Lepró, X.; Zakhidov, A.A.; Lee, J.; Spinks, G.M. Woven-yarn thermoelectric textiles. Adv. Mater. 2016, 28, 5038-5044. [CrossRef]

32. Li, P.; Guo, Y.; Mu, J.; Wang, H.; Zhang, Q.; Li, Y. Single-walled carbon nanotubes/polyaniline-coated polyester thermoelectric textile with good interface stability prepared by ultrasonic induction. RSC Adv. 2016, 6, 90347-90353. [CrossRef]

33. Lu, Z.; Zhang, H.; Mao, C.; Li, C.M. Silk fabric-based wearable thermoelectric generator for energy harvesting from the human body. Appl. Energy 2016, 164, 57-63. [CrossRef]

34. Wu, Q.; Hu, J. Waterborne polyurethane based thermoelectric composites and their application potential in wearable thermoelectric textiles. Compos. Part B Eng. 2016, 107, 59-66. [CrossRef]

35. Leonov, V. Thermoelectric energy harvesting of human body heat for wearable sensors. IEEE Sens. J. 2013, 13, 2284-2291. [CrossRef]

36. Seeberg, T.M.; Røyset, A.; Jahren, S.; Strisland, F. Printed organic conductive polymers thermocouples in textile and smart clothing applications. In Proceedings of the 2011 Annual International Conference of the IEEE Engineering in Medicine and Biology Society, Boston, MA, USA, 30 August-3 September 2011; pp. 3278-3281.

37. Kim, S.J.; We, J.H.; Cho, B.J. A wearable thermoelectric generator fabricated on a glass fabric. Energy Environ. Sci. 2014, 7, 1959-1965. [CrossRef]

38. Sebald, G.; Guyomar, D.; Agbossou, A. On thermoelectric and pyroelectric energy harvesting. Smart Mater. Struct. 2009, 18, 125006. [CrossRef]

39. Yang, B.; Yun, K. Piezoelectric shell structures as wearable energy harvesters for effective power generation at low-frequency movement. Sens. Actuators A Phys. 2012, 188, 427-433. [CrossRef]

40. Chang, J.; Dommer, M.; Chang, C.; Lin, L. Piezoelectric nanofibers for energy scavenging applications. Nano Energy 2012, 1, 356-371. [CrossRef]

41. Zeng, W.; Tao, X.; Chen, S.; Shang, S.; Chan, H.L.W.; Choy, S.H. Highly durable all-fiber nanogenerator for mechanical energy harvesting. Energy Environ. Sci. 2013, 6, 2631-2638. [CrossRef]

42. Åkerfeldt, M.; Nilsson, E.; Gillgard, P.; Walkenström, P. Textile piezoelectric sensors-melt spun bi-component poly (vinylidene fluoride) fibres with conductive cores and poly (3, 4-ethylene dioxythiophene)-poly (styrene sulfonate) coating as the outer electrode. Fash. Text. 2014, 1, 13. [CrossRef]

43. Yun, D.; Park, J.; Yun, K. Highly stretchable energy harvester using piezoelectric helical structure for wearable applications. Electron. Lett. 2015, 51, 284-285. [CrossRef]

44. Zhang, M.; Gao, T.; Wang, J.; Liao, J.; Qiu, Y.; Yang, Q.; Xue, H.; Shi, Z.; Zhao, Y.; Xiong, Z. A hybrid fibers based wearable fabric piezoelectric nanogenerator for energy harvesting application. Nano Energy 2015, 13, 298-305. [CrossRef]

45. Song, S.; Ahn, Y.; Yun, K. Scalable textile energy harvester in woven piezoelectric structures. In Proceedings of the 2015 Transducers-2015 18th International Conference on Solid-State Sensors, Actuators and Microsystems (TRANSDUCERS), Anchorage, AK, USA, 21-25 June 2015; pp. 708-709.

46. Anand, S.; Soin, N.; Shah, T.H.; Siores, E. Energy harvesting "3-D knitted spacer" based piezoelectric textiles. In IOP Conference Series: Materials Science and Engineering; IOP Publishing: Bristol, UK, 2016; p. 012001. 
47. Zhao, J.; You, Z. Models for 31-mode PVDF energy harvester for wearable applications. Sci. World J. 2014, 2014, 1-11. [CrossRef]

48. Soin, N.; Shah, T.H.; Anand, S.C.; Geng, J.; Pornwannachai, W.; Mandal, P.; Reid, D.; Sharma, S.; Hadimani, R.L.; Bayramol, D.V. Novel “3-D spacer" all fibre piezoelectric textiles for energy harvesting applications. Energy Environ. Sci. 2014, 7, 1670-1679. [CrossRef]

49. Waqar, S.; Wang, L.; John, S. Piezoelectric energy harvesting from intelligent textiles. In Electronic Textiles; Elsevier: Amsterdam, The Netherlands, 2015; pp. 173-197.

50. Qin, Y.; Wang, X.; Wang, Z.L. Microfibre-nanowire hybrid structure for energy scavenging. Nature 2008, 451, 809-813. [CrossRef]

51. Wang, Z.L. Triboelectric nanogenerators as new energy technology for self-powered systems and as active mechanical and chemical sensors. ACS Nano 2013, 7, 9533-9557. [CrossRef] [PubMed]

52. Ha, M.; Park, J.; Lee, Y.; Ko, H. Triboelectric generators and sensors for self-powered wearable electronics. ACS Nano 2015, 9, 3421-3427. [CrossRef]

53. Cheng, X.; Meng, B.; Zhang, X.; Han, M.; Su, Z.; Zhang, H. Wearable electrode-free triboelectric generator for harvesting biomechanical energy. Nano Energy 2015, 12, 19-25. [CrossRef]

54. Tang, W.; Zhou, T.; Zhang, C.; Fan, F.R.; Han, C.B.; Wang, Z.L. A power-transformed-and-managed triboelectric nanogenerator and its applications in a self-powered wireless sensing node. Nanotechnology 2014, 25, 225402. [CrossRef] [PubMed]

55. Lee, S.; Ko, W.; Oh, Y.; Lee, J.; Baek, G.; Lee, Y.; Sohn, J.; Cha, S.; Kim, J.; Park, J. Triboelectric energy harvester based on wearable textile platforms employing various surface morphologies. Nano Energy 2015, 12, 410-418. [CrossRef]

56. Pu, X.; Li, L.; Song, H.; Du, C.; Zhao, Z.; Jiang, C.; Cao, G.; Hu, W.; Wang, Z.L. A self-charging power unit by integration of a textile triboelectric nanogenerator and a flexible lithium-ion battery for wearable electronics. Adv. Mater. 2015, 27, 2472-2478. [CrossRef]

57. Liu, L.; Pan, J.; Chen, P.; Zhang, J.; Yu, X.; Ding, X.; Wang, B.; Sun, X.; Peng, H. A triboelectric textile templated by a three-dimensionally penetrated fabric. J. Mater. Chem. A 2016, 4, 6077-6083. [CrossRef]

58. Pu, X.; Song, W.; Liu, M.; Sun, C.; Du, C.; Jiang, C.; Huang, X.; Zou, D.; Hu, W.; Wang, Z.L. Wearable power-textiles by integrating fabric triboelectric nanogenerators and fiber-shaped dye-sensitized solar cells. Adv. Energy Mater. 2016, 6, 1601048. [CrossRef]

59. Zhao, Z.; Yan, C.; Liu, Z.; Fu, X.; Peng, L.; Hu, Y.; Zheng, Z. Machine-washable textile triboelectric nanogenerators for effective human respiratory monitoring through loom weaving of metallic yarns. Adv. Mater. 2016, 28, 10267-10274. [CrossRef]

60. Zhu, M.; Huang, Y.; Ng, W.S.; Liu, J.; Wang, Z.; Wang, Z.; Hu, H.; Zhi, C. 3D spacer fabric based multifunctional triboelectric nanogenerator with great feasibility for mechanized large-scale production. Nano Energy 2016, 27, 439-446. [CrossRef]

61. Zhu, G.; Zhou, Y.S.; Bai, P.; Meng, X.S.; Jing, Q.; Chen, J.; Wang, Z.L. A shape-adaptive thin-film-based approach for $50 \%$ high-efficiency energy generation through micro-grating sliding electrification. Adv. Mater. 2014, 26, 3788-3796. [CrossRef] [PubMed]

62. Niu, S.; Wang, Z.L. Theoretical systems of triboelectric nanogenerators. Nano Energy 2015, 14, 161-192. [CrossRef]

63. Zhao, K.; Wang, Y.; Han, L.; Wang, Y.; Luo, X.; Zhang, Z.; Yang, Y. Nanogenerator-based self-charging energy storage devices. Nano Micro Lett. 2019, 11, 19. [CrossRef]

64. Wang, Z.L.; Chen, J.; Lin, L. Progress in triboelectric nanogenerators as a new energy technology and self-powered sensors. Energy Environ. Sci. 2015, 8, 2250-2282. [CrossRef]

65. Ylli, K.; Hoffmann, D.; Folkmer, B.; Manoli, Y. Design, fabrication and characterization of an inductive human motion energy harvester for application in shoes. In Journal of Physics: Conference Series; IOP Publishing: Bristol, UK, 2013; p. 012012.

66. Teichmann, D.; Kuhn, A.; Leonhardt, S.; Walter, M. The MAIN shirt: A textile-integrated magnetic induction sensor array. Sensors 2014, 14, 1039-1056. [CrossRef] [PubMed]

67. Zhang, Q.; Wang, Y.; Kim, E.S. Electromagnetic energy harvester with flexible coils and magnetic spring for 1-10 Hz resonance. J. Microelectromech. Syst. 2015, 24, 1193-1206. [CrossRef]

68. Cho, H.; Yang, J.; Park, S.; Yun, K.; Kim, Y.; Lee, J. An exploratory study on the feasibility of a foot gear type energy harvester using a textile coil inductor. J. Electr. Eng. Technol. 2016, 11, 1210-1215. [CrossRef] 
69. Lee, H.; Roh, J. Wearable electromagnetic energy-harvesting textiles based on human walking. Text. Res. J. 2019, 89, 2532-2541. [CrossRef]

70. Becquerel, M.E. Mémoire sur les effets électriques produits sous l'influence des rayons solaires. Comptes Rendus De L'Academie Des Sci. 1839, 9, 561-567.

71. McEvoy, A.; Markvart, T. Solar cells: Materials, Manufacture and Operation; Academic Press: Cambridge, MA, USA, 2012.

72. Green, M.A.; Dunlop, E.D.; Levi, D.H.; Hohl-Ebinger, J.; Yoshita, M.; Ho-Baillie, A.W. Solar cell efficiency tables (version 54). Prog. Photovolt. Res. Appl. 2019, 27, 565-575. [CrossRef]

73. Nocito, C.; Koncar, V. Flexible photovoltaic cells embedded into textile structures. In Smart Textiles and Their Applications; Elsevier: Amsterdam, The Netherlands, 2016; pp. 401-422.

74. Beam Backpack-The Most Advanced Solar Power Backpack. Available online: https://www.kickstarter.com/ projects/1265473734/beam-backpack-the-most-advanced-solar-power-backpa (accessed on 16 October 2020).

75. Kingsons Beam Backpack-The Most Advanced Solar Power Backpack-Waterproof, Anti-Theft Laptop Bag. Available online: https://www.amazon.co.uk/Kingsons-Beam-Backpack-Waterproof-Anti-Theft/dp/ B07L9R76W3/ref=cm_cr_arp_d_product_top?ie=UTF8 (accessed on 16 October 2020).

76. Zenith-Solar Backpack. Available online: https://www.sunslice-solar.com/products/zenith (accessed on 16 October 2020).

77. Tommy Hilfiger's Solar-Powered Jacket-Wearable Tech in Review. Available online: https://www.forbes.com/ sites/rachelarthur/2014/11/20/tommy-hilfigers-solar-powered-jacket-wearable-tech-in-review/ (accessed on 1 April 2020).

78. Tommy Hilfiger Solar Clothing. Available online: http://www.pvilion.com/solar-clothing (accessed on 16 October 2020).

79. Wearable Solar Shirt. Available online: http://www.paulinevandongen.nl/project/wearable-solar-shirt/ (accessed on 1 April 2020).

80. Wearable Solar Dress. Available online: http://www.paulinevandongen.nl/project/wearable-solar/ (accessed on 1 April 2020).

81. Smelik, A.; Toussaint, L.; Van Dongen, P. Solar fashion: An embodied approach to wearable technology. Int. J. Fash. Stud. 2016, 3, 287-303. [CrossRef]

82. Haugen, A.E. Sun-Powered Vest. U.S. Patent 4,827,534, 9 May 1989.

83. Jaynes, S. Solar Powered Survival Suit. U.S. Patent Application US 2007/0151593 A1, 5 July 2007.

84. Orandi, K. Solar Powered Motorcycle Jacket. U.S. Patent Application US 2009/0144887 A1, 11 June 2009.

85. Energy Conversion Devices, Inc. Retractable Power Supply. U.S. Patent 4,636,579, 13 January 1987.

86. Ma, J. Power Generation Umbrella. U.S. Patent Application US 2011/0290288 A1, 1 December 2011.

87. ILAND Green Technologies SA. Photovoltaic Blind. U.S. Patent Application US 2014/0027069 A1, 30 January 2014.

88. Heidenreich, D.C. Photovoltaic Awning Structures. U.S. Patent Application US 2009/0014130 A1, 15 January 2009.

89. Lambey, J. Blind or Awning Photo-Generator. U.S. Patent Application US 2008/0163984 A1, 10 July 2008.

90. Dickson Constant. Awning Type Solar Protection Device Equipped with an Electrical Power Production System. U.S. Patent 9,133,662 B2, 15 September 2015.

91. Palo Alto Research Center Incorporated. Photovoltaic Modules on a Textile Substrate. U.S. Patent Application US 2011/0290304 A1, 1 December 2011.

92. Pvilion, Inc. Systems and Methods for Applying Flexible Solar Panels to Flexible Underlying Membranes. U.S. Patent Application US 2019/0288639 A1, 19 September 2019.

93. Fuchi Textile Co., Ltd. Flexible Photovoltaic Apparatus. U.S. Patent Application US 2015/0059825 A1, 5 March 2015.

94. Ascent Solar Technologies, Inc. Photovoltaic Assembly and Associated Methods. U.S. Patent Application US 2014/0083485 A1, 27 March 2014.

95. Infineon Technologies Americas Corp. Flexible Fabric Support Structure for Photovoltaic Cells. U.S. Patent 3,255,047, 7 June 1966.

96. SOLANNEX Inc. Collector Grid and Interconnect Structures for Photovoltaic Arrays and Modules. U.S. Patent 8,138,413 B2, 20 March 2012. 
97. Forster Rohner AG Method for Attaching Flat Electronic Components Onto a Flexible Surface Structure. U.S. Patent Application US 2011/0240091 A1, 6 October 2011.

98. Cruz-Campa, J.L.; Okandan, M.; Resnick, P.J.; Clews, P.; Pluym, T.; Grubbs, R.K.; Gupta, V.P.; Zubia, D.; Nielson, G.N. Microsystems enabled photovoltaics: $14.9 \%$ efficient $14 \mu \mathrm{m}$ thick crystalline silicon solar cell. Sol. Energy Mater. Sol. Cells 2011, 95, 551-558. [CrossRef]

99. Gu, T.; Agrawal, G.; Vessey, A.; Sweatt, W.C.; Jared, B.H.; Cruz-Campa, J.L.; Goeke, R.; Miller, W.K.; Zamora, D.L.; Langlois, E. Micro-concentrator module for Microsystems-Enabled Photovoltaics: Optical performance characterization, modelling and analysis. In Proceedings of the 2015 IEEE 42nd Photovoltaic Specialist Conference (PVSC), New Orleans, LA, USA, 14-19 June 2015; pp. 1-5.

100. Sandia's Solar Glitter Closer to Market with New Licensing Agreement. Available online: https://phys.org/ news/2017-02-sandia-solar-glitter-closer-agreement.html (accessed on 3 April 2020).

101. Satharasinghe, A.; Hughes-Riley, T.; Dias, T. An investigation of a wash durable solar energy harvesting textile. Prog. Photovolt. Res. Appl. 2019, 28, 578-592. [CrossRef]

102. Du, P.; Song, L.; Xiong, J.; Wang, L.; Li, N. A photovoltaic smart textile and a photocatalytic functional textile based on co-electrospun $\mathrm{TiO} 2 / \mathrm{MgO}$ core-sheath nanorods: Novel textiles of integrating energy and environmental science with textile research. Text. Res. J. 2013, 83, 1690-1702. [CrossRef]

103. Krebs, F.C.; Biancardo, M.; Winther-Jensen, B.; Spanggard, H.; Alstrup, J. Strategies for incorporation of polymer photovoltaics into garments and textiles. Sol. Energy Mater. Sol. Cells 2006, 90, 1058-1067. [CrossRef]

104. Jinno, H.; Fukuda, K.; Xu, X.; Park, S.; Suzuki, Y.; Koizumi, M.; Yokota, T.; Osaka, I.; Takimiya, K.; Someya, T. Stretchable and waterproof elastomer-coated organic photovoltaics for washable electronic textile applications. Nat. Energy 2017, 2, 780-785. [CrossRef]

105. Lee, S.; Lee, Y.; Park, J.; Choi, D. Stitchable organic photovoltaic cells with textile electrodes. Nano Energy 2014, 9, 88-93. [CrossRef]

106. Liu, J.; Li, Y.; Arumugam, S.; Tudor, J.; Beeby, S. Screen printed dye-sensitized solar cells (DSSCs) on woven polyester cotton fabric for wearable energy harvesting applications. Mater. Today Proc. 2018, 5, 13753-13758. [CrossRef]

107. Liu, J.; Li, Y.; Yong, S.; Arumugam, S.; Beeby, S. Flexible printed monolithic-structured solid-state dye sensitized solar cells on woven glass fibre textile for wearable energy harvesting applications. Sci. Rep. 2019, 9, 1-11. [CrossRef]

108. Lam, J.; Chen, J.; Tsai, P.; Hsieh, Y.; Chueh, C.; Tung, S.; Chen, W. A stable, efficient textile-based flexible perovskite solar cell with improved washable and deployable capabilities for wearable device applications. RSC Adv. 2017, 7, 54361-54368. [CrossRef]

109. Jung, J.W.; Bae, J.H.; Ko, J.H.; Lee, W. Fully solution-processed indium tin oxide-free textile-based flexible solar cells made of an organic-inorganic perovskite absorber: Toward a wearable power source. J. Power Sources 2018, 402, 327-332. [CrossRef]

110. Bedeloglu, A.; Demir, A.; Bozkurt, Y.; Sariciftci, N.S. A flexible textile structure based on polymeric photovoltaics using transparent cathode. Synth. Met. 2009, 159, 2043-2048. [CrossRef]

111. Lipomi, D.J.; Tee, B.C.; Vosgueritchian, M.; Bao, Z. Stretchable organic solar cells. Adv. Mater. 2011, 23, 1771-1775. [CrossRef] [PubMed]

112. Kaltenbrunner, M.; White, M.S.; GÅowacki, E.D.; Sekitani, T.; Someya, T.; Sariciftci, N.S.; Bauer, S. Ultrathin and lightweight organic solar cells with high flexibility. Nat. Commun. 2012, 3, 770. [CrossRef]

113. Kylberg, W.; De Castro, F.A.; Chabrecek, P.; Sonderegger, U.; Chu, B.T.; Nüesch, F.; Hany, R. Woven electrodes for flexible organic photovoltaic cells. Adv. Mater. 2011, 23, 1015-1019. [CrossRef]

114. Arumugam, S.; Li, Y.; Senthilarasu, S.; Torah, R.; Kanibolotsky, A.L.; Inigo, A.R.; Skabara, P.J.; Beeby, S.P. Fully spray-coated organic solar cells on woven polyester cotton fabrics for wearable energy harvesting applications. J. Mater. Chem. A 2016, 4, 5561-5568. [CrossRef]

115. Jeong, E.G.; Jeon, Y.; Cho, S.H.; Choi, K.C. Textile-based washable polymer solar cells for optoelectronic modules: Toward self-powered smart clothing. Energy Environ. Sci. 2019, 12, 1878-1889. [CrossRef]

116. Xu, J.; Li, M.; Wu, L.; Sun, Y.; Zhu, L.; Gu, S.; Liu, L.; Bai, Z.; Fang, D.; Xu, W. A flexible polypyrrole-coated fabric counter electrode for dye-sensitized solar cells. J. Power Sources 2014, 257, 230-236. [CrossRef]

117. Xu, Q.; Li, M.; Yan, P.; Wei, C.; Fang, L.; Wei, W.; Bao, H.; Xu, J.; Xu, W. Polypyrrole-coated cotton fabrics prepared by electrochemical polymerization as textile counter electrode for dye-sensitized solar cells. Org. Electron. 2016, 29, 107-113. [CrossRef] 
118. Yun, M.J.; Cha, S.I.; Seo, S.H.; Kim, H.S.; Lee, D.Y. Float printing deposition to control the morphology of TiO 2 photoanodes on woven textile metal substrates for TCO-free flexible dye-sensitized solar cells. RSC Adv. 2016, 6, 67331-67339. [CrossRef]

119. Opwis, K.; Gutmann, J.S.; Lagunas Alonso, A.R.; Rodriguez Henche, M.J.; Ezquer Mayo, M.; Breuil, F.; Leonardi, E.; Sorbello, L. Preparation of a textile-based dye-sensitized solar cell. Int. J. Photoenergy 2016, 2016, 3796074. [CrossRef]

120. Yun, M.J.; Sim, Y.H.; Cha, S.I.; Seo, S.H.; Lee, D.Y. Three-dimensional textile platform for electrochemical devices and its application to dye-sensitized solar cells. Sci. Rep. 2019, 9, 2322. [CrossRef] [PubMed]

121. Song, L.; Yin, X.; Xie, X.; Du, P.; Xiong, J.; Ko, F. Highly flexible TiO2/C nanofibrous film for flexible dye-sensitized solar cells as a platinum-and transparent conducting oxide-free flexible counter electrode. Electrochim. Acta 2017, 255, 256-265. [CrossRef]

122. Song, L.; Wang, T.; Jing, W.; Xie, X.; Du, P.; Xiong, J. High flexibility and electrocatalytic activity MoS2/TiC/carbon nanofibrous film for flexible dye-sensitized solar cell based photovoltaic textile. Mater. Res. Bull. 2019, 118, 110522. [CrossRef]

123. Knittel, D.; Köntges, M.; Heinemeyer, F.; Schollmeyer, E. Coatings on textiles for Cu(In,Ga)Se2 photovoltaic cell formation on textile carriers: Preparation of $\mathrm{Cu}(\mathrm{In}, \mathrm{Ga}) \mathrm{Se} 2$ solar cells on glass-fiber textiles. J. Appl. Polym. Sci. 2009, 115, 2763-2766. [CrossRef]

124. Plentz, J.; Andrä, G.; Pliewischkies, T.; Brückner, U.; Eisenhawer, B.; Falk, F. Amorphous silicon thin-film solar cells on glass fiber textiles. Mater. Sci. Eng. B 2016, 204, 34-37. [CrossRef]

125. Ramier, J.; Plummer, C.; Leterrier, Y.; Månson, J.; Eckert, B.; Gaudiana, R. Mechanical integrity of dye-sensitized photovoltaic fibers. Renew. Energy 2008, 33, 314-319. [CrossRef]

126. Lv, Z.; Fu, Y.; Hou, S.; Wang, D.; Wu, H.; Zhang, C.; Chu, Z.; Zou, D. Large size, high efficiency fiber-shaped dye-sensitized solar cells. Phys. Chem. Chem. Phys. 2011, 13, 10076-10083. [CrossRef] [PubMed]

127. Yang, Z.; Sun, H.; Chen, T.; Qiu, L.; Luo, Y.; Peng, H. Photovoltaic wire derived from a graphene composite fiber achieving an 8.45\% energy conversion efficiency. Angew. Chem. Int. Ed. 2013, 52, 7545-7548. [CrossRef] [PubMed]

128. Liang, J.; Zhang, G.; Sun, W.; Dong, P. High efficiency flexible fiber-type dye-sensitized solar cells with multi-working electrodes. Nano Energy 2015, 12, 501-509. [CrossRef]

129. Chen, T.; Qiu, L.; Cai, Z.; Gong, F.; Yang, Z.; Wang, Z.; Peng, H. Intertwined aligned carbon nanotube fiber based dye-sensitized solar cells. Nano Lett. 2012, 12, 2568-2572. [CrossRef] [PubMed]

130. Velten, J.; Kuanyshbekova, Z.; Göktepe, Ö.; Göktepe, F.; Zakhidov, A. Weavable dye sensitized solar cells exploiting carbon nanotube yarns. Appl. Phys. Lett. 2013, 102, 203902. [CrossRef]

131. Yan, J.; Uddin, M.J.; Dickens, T.J.; Daramola, D.E.; Okoli, O.I. 3D wire-shaped dye-sensitized solar cells in solid state using carbon nanotube yarns with hybrid photovoltaic structure. Adv. Mater. Interfaces 2014, 1, 1400075. [CrossRef]

132. Chen, T.; Qiu, L.; Kia, H.G.; Yang, Z.; Peng, H. Designing aligned inorganic nanotubes at the electrode interface: Towards highly efficient photovoltaic wires. Adv. Mater. 2012, 24, 4623-4628. [CrossRef] [PubMed]

133. Zhang, S.; Ji, C.; Bian, Z.; Yu, P.; Zhang, L.; Liu, D.; Shi, E.; Shang, Y.; Peng, H.; Cheng, Q. Porous, platinum nanoparticle-adsorbed carbon nanotube yarns for efficient fiber solar cells. ACS Nano 2012, 6, 7191-7198. [CrossRef] [PubMed]

134. Uddin, M.J.; Davies, B.; Dickens, T.J.; Okoli, O.I. Self-aligned carbon nanotubes yarns (CNY) with efficient optoelectronic interface for microyarn shaped 3D photovoltaic cells. Sol. Energy Mater. Sol. Cells 2013, 115, 166-171. [CrossRef]

135. Fu, X.; Sun, H.; Xie, S.; Zhang, J.; Pan, Z.; Liao, M.; Xu, L.; Li, Z.; Wang, B.; Sun, X. A fiber-shaped solar cell showing a record power conversion efficiency of 10\%. J. Mater. Chem. A 2018, 6, 45-51. [CrossRef]

136. Qiu, L.; Deng, J.; Lu, X.; Yang, Z.; Peng, H. Integrating perovskite solar cells into a flexible fiber. Angew. Chem. Int. Ed. 2014, 53, 10425-10428. [CrossRef]

137. He, S.; Qiu, L.; Fang, X.; Guan, G.; Chen, P.; Zhang, Z.; Peng, H. Radically grown obelisk-like ZnO arrays for perovskite solar cell fibers and fabrics through a mild solution process. J. Mater. Chem. A 2015, 3, 9406-9410. [CrossRef]

138. Hu, H.; Yan, K.; Peng, M.; Yu, X.; Chen, S.; Chen, B.; Dong, B.; Gao, X.; Zou, D. Fiber-shaped perovskite solar cells with 5.3\% efficiency. J. Mater. Chem. A 2016, 4, 3901-3906. [CrossRef] 
139. Li, R.; Xiang, X.; Tong, X.; Zou, J.; Li, Q. Wearable double-twisted fibrous perovskite solar cell. Adv. Mater. 2015, 27, 3831-3835. [CrossRef] [PubMed]

140. Chuangchote, S.; Sagawa, T.; Yoshikawa, S. Design of metal wires-based organic photovoltaic cells. Energy Procedia 2011, 9, 553-558. [CrossRef]

141. Lee, M.R.; Eckert, R.D.; Forberich, K.; Dennler, G.; Brabec, C.J.; Gaudiana, R.A. Solar power wires based on organic photovoltaic materials. Science 2009, 324, 232-235. [CrossRef] [PubMed]

142. Liu, D.; Zhao, M.; Li, Y.; Bian, Z.; Zhang, L.; Shang, Y.; Xia, X.; Zhang, S.; Yun, D.; Liu, Z. Solid-state, polymer-based fiber solar cells with carbon nanotube electrodes. ACS Nano 2012, 6, 11027-11034. [CrossRef]

143. Zhang, L.; Shi, E.; Li, Z.; Li, P.; Jia, Y.; Ji, C.; Wei, J.; Wang, K.; Zhu, H.; Wu, D. Wire-supported CdSe nanowire array photoelectrochemical solar cells. Phys. Chem. Chem. Phys. 2012, 14, 3583-3588. [CrossRef]

144. Zhang, L.; Song, L.; Tian, Q.; Kuang, X.; Hu, J.; Liu, J.; Yang, J.; Chen, Z. Flexible fiber-shaped CuInSe2 solar cells with single-wire-structure: Design, construction and performance. Nano Energy 2012, 1, 769-776. [CrossRef]

145. O'Connor, B.; Pipe, K.P.; Shtein, M. Fiber based organic photovoltaic devices. Appl. Phys. Lett. 2008, 92, 172. [CrossRef]

146. Toivola, M.; Ferenets, M.; Lund, P.; Harlin, A. Photovoltaic fiber. Thin Solid Films 2009, 517, $2799-2802$. [CrossRef]

147. Bedeloglu, A.; Demir, A.; Bozkurt, Y.; Sariciftci, N.S. A photovoltaic fiber design for smart textiles. Text. Res. J. 2010, 80, 1065-1074. [CrossRef]

148. Yang, Z.; Deng, J.; Sun, X.; Li, H.; Peng, H. Stretchable, wearable dye-sensitized solar cells. Adv. Mater. 2014, 26, 2643-2647. [CrossRef]

149. Zhang, L.; Shi, E.; Ji, C.; Li, Z.; Li, P.; Shang, Y.; Li, Y.; Wei, J.; Wang, K.; Zhu, H. Fiber and fabric solar cells by directly weaving carbon nanotube yarns with CdSe nanowire-based electrodes. Nanoscale 2012, 4, 4954-4959. [CrossRef] [PubMed]

150. Pan, S.; Yang, Z.; Chen, P.; Deng, J.; Li, H.; Peng, H. Wearable solar cells by stacking textile electrodes. Angew. Chem. Int. Ed. 2014, 53, 6110-6114. [CrossRef]

151. Chai, Z.; Zhang, N.; Sun, P.; Huang, Y.; Zhao, C.; Fan, H.J.; Fan, X.; Mai, W. Tailorable and wearable textile devices for solar energy harvesting and simultaneous storage. ACS Nano 2016, 10, 9201-9207. [CrossRef] [PubMed]

152. Zhang, N.; Chen, J.; Huang, Y.; Guo, W.; Yang, J.; Du, J.; Fan, X.; Tao, C. A wearable all-solid photovoltaic textile. Adv. Mater. 2016, 28, 263-269. [CrossRef]

153. Liu, P.; Gao, Z.; Xu, L.; Shi, X.; Fu, X.; Li, K.; Zhang, B.; Sun, X.; Peng, H. Polymer solar cell textiles with interlaced cathode and anode fibers. J. Mater. Chem. A 2018, 6, 19947-19953. [CrossRef]

154. Chen, J.; Huang, Y.; Zhang, N.; Zou, H.; Liu, R.; Tao, C.; Fan, X.; Wang, Z.L. Micro-cable structured textile for simultaneously harvesting solar and mechanical energy. Nat. Energy 2016, 1, 16138. [CrossRef]

155. Krebs, F.C.; Hösel, M. The solar textile challenge: How it will not work and where it might. ChemSusChem 2015, 8, 966-969. [CrossRef]

156. Yun, M.J.; Cha, S.I.; Seo, S.H.; Lee, D.Y. Insertion of dye-sensitized solar cells in textiles using a conventional weaving process. Sci. Rep. 2015, 5, 11022. [CrossRef]

157. Kuhlmann, J.C.; de Moor, H.; Driesser, M.; Bottenberg, E.; Spee, C.; Brinks, G.J. Development of a Universal Solar Energy Harvesting System Suited for Textile Integration Including Flexible Energy Storage. J. Fash. Technol. Text. Eng. 2018. [CrossRef]

158. Sundarrajan, S.; Murugan, R.; Nair, A.S.; Ramakrishna, S. Fabrication of P3HT/PCBM solar cloth by electrospinning technique. Mater. Lett. 2010, 64, 2369-2372. [CrossRef]

159. Sun, K.C.; Sahito, I.A.; Noh, J.W.; Yeo, S.Y.; Im, J.N.; Yi, S.C.; Kim, Y.S.; Jeong, S.H. Highly efficient and durable dye-sensitized solar cells based on a wet-laid PET membrane electrolyte. J. Mater. Chem. A 2016, 4, 458-465. [CrossRef]

160. Juhász Junger, I.; Wehlage, D.; Böttjer, R.; Grothe, T.; Juhász, L.; Grassmann, C.; Blachowicz, T.; Ehrmann, A. Dye-sensitized solar cells with electrospun nanofiber mat-based counter electrodes. Materials 2018, 11, 1604. [CrossRef] [PubMed]

161. Lee, J.; Park, N. Chemical Approaches for Stabilizing Perovskite Solar Cells. Adv. Energy Mater. 2020, 10, 1903249. [CrossRef] 
162. Kalantarian, H.; Alshurafa, N.; Pourhomayoun, M.; Sarrafzadeh, M. Power optimization for wearable devices. In Proceedings of the 2015 IEEE International Conference on Pervasive Computing and Communication Workshops (PerCom Workshops), St. Louis, MO, USA, 23-27 March 2015; pp. 568-573.

163. Carroll, A.; Heiser, G. An Analysis of Power Consumption in a Smartphone. In Proceedings of the 2010 USENIX Conference on USENIX Annual Technical Conference, Boston, MA, USA, 22-25 June 2010; p. 21.

Publisher's Note: MDPI stays neutral with regard to jurisdictional claims in published maps and institutional affiliations.

(C) 2020 by the authors. Licensee MDPI, Basel, Switzerland. This article is an open access article distributed under the terms and conditions of the Creative Commons Attribution (CC BY) license (http://creativecommons.org/licenses/by/4.0/). 